\title{
Análisis agustiniano de «crescite et multiplicamini» (Gen 1,28)
}

\section{PATRÍSTICA ANTERIOR A SAN AGUSTÍN}

Sabido es que las corrientes antiguas de mayor incidencia en la vida cristiana -gnosticismo, neoplatonismo, encratismo y estoicismo por citar algunas - condicionaron a los autores religiosos en su elaboración filosóficoteológica de la palabra revelada, incluso arrastrando alguna vez, los gnósticos mayormente, hasta una especie de racionalización del misterio. Gen 1,28 plan-

* Las abreviaturas vienen casi todas en el manual S. Schwertner, IAGAT. International Abkürzungswerzeichnis für Theologie und Grenzgebiete. Walter de Gruyter, Berlin, New York 1974. La versión española de los textos agustinianos suele ser de las Obras de San Agustín publicadas en la BAC, que citamos según la numeración general de la serie. Convencionales nuestras son:

Actes AA.VV., Actes du Colloque de Chevetogne -22/26 sept. 1969-. Écriture et Culture Philosophique dans la Pensée de Grégoire de Nysse, Brill, Leiden 1971.

ATs $\quad$ AA.VV., Arché e Telos. L'Antropologia di Origine e di Gregorio di Nissa. Analisis storico-religiosa. Atti del Colloquio Milano, 17-19 maggio 1979. Pubblicati a cura di U. Bianchi con la cooperazioni della Università Cattolica del Sacro Cuore, Milano 1981.

BAC 422 Instituto Patristico Augustinianum. PATROLOGIA III. La Edad de oro de la literatura patrística latina. BAC 422, Madrid 1981.

BAug Bibliothèque Augustinienne, París.

DCU AA.V., L 'Doppia Creazione' dell'uomo negli Elessandrini, nei Cappadoci e nella gnosi, a cura di Ugo Bianchi. Serie Prometeo, Orfeo, Adamo, Edizioni dell'Ateneo/Bizarri, Roma 1978.

Paola Pisi Genesis e Phthorá. Le motivazioni Protologiche della verginità in Gregorio di Nissa e nella tradizione dell'enkrateia. Serie: Prometeo, Orfeo, Adamo, Edizioni dell'Ateneo, s.p.a., Roma 1981.

SPM AA.VV., Etica sessuale e matrimonio den cristianesimo delle origini, a cura di Raniero Cantalamessa, Studia Patristica Mediolanensia 5, Vita e Pensiero, Milano.... 
tea al respecto uno de los estudios patrísticos más apasionantes. El fin de estas páginas es comprobarlo en san Agustín, mas como sería difícil sin la patrística anterior, se impone entonces el estudio riguroso de patrología comparada.

Ya los primeros capítulos del Génesis tratan de cosmología y antropología generales, y Gen 1,28, antes que fenomenología matrimonial, es antropología pura. Ocurre sin embargo que en antropología topamos pronto con elementos de la constitución física del hombre tal y como ahora es que no pertenecen de modo verosímil a la physis humana no ya, digamos, como ésta fue concebida por el primer deseo creador de Dios, pero ni siquiera según quedó luego en el estado de integridad primordial. El problema reside en lo que Dios había incorporado a la actual constitución física del hombre. Puestos así, habrá que averiguar también si tal añadidura fue necesaria o sólo de conveniencia. Finalmente, y una vez adelantado que discurrimos dentro de problemáticas antropológicas, resta advertir de sus dimensiones de protología y escatología. Estos puntos, y más que irán saliendo, exige un análisis teológico de Gen $1,28{ }^{1}$.

Del dato bíblico tampoco hay que prescindir. El juicio bíblico-teológico que Gen 1,28 mereció a la patrística preagustiniana y al propio Obispo de $\mathrm{Hi}$ pona arrojará al final, cabe esperarlo, una idea clarificadora, pero antes, y como inciso introductorio, admítase que en Gen 1,27-28 figura la diversidad sexual como obra con la cual Dios ha querido asegurar la multiplicación de los hombres y de los animales. No se apunta tanto, por consiguiente, al matrimonio como convivencia, cuanto al acoplamiento sexual necesario para la procreación. Ningún legislador del AT se refiere con tales relatos al matrimonio, visto por lo demás como hecho humano, como institución natural que está ahí. Su interés proviene, más bien, de haberles agregado la noticia de la creación y, para lo que nos concierne, de las consecuencias derivadas en orden a interpretar multiplicamini. Un repaso a la exégesis patrística de Gen 1,28 pondrá de manifiesto lo difícil que a los Padres se les hizo esta labor, los medios arbitrados para superarla y el panorama teológico abierto con dicho análisis antes y después de san Agustín.

\section{DiverSAS SENTENCIAS PATRÍSTICAS}

Cuando el Obispo de Hipona escribe De bono coniugali -es el año $401^{2}$ - parte de la antropología paradisíaca y con esa bipolar magnitud o su-

1. Cf. U. Bianchi, ATs 9-28; Id., DCU 3-21.83-115; Id., en: Origeniana II, Edizioni dell'Ateneo, Roma 1980, 33-56.

2. Cf. Retract. II, 25 (PL 32,640, CASEL 36,161); De Gen, ad lit. IX, 7,12 (PL 34,397, 
prarrealidad típica del hombre agustiniano: bendición divina y pecado de los protoparentes ${ }^{3}$. Para san Agustín esta caída fue siempre el diapasón con el que timbrar la variada gama cromática de los problemas teológicos, Lo demuestra bien aquí al distinguir entre lo que somos y lo que pudimos ser; entre el matrimonio factual y el hipotético (sin prevaricación por medio); entre un crescite et multiplicamini antelapsario y postlapsario. ¿Cómo hubiera sido el multiplicaos de no haber pecado el primer hombre? Esta es la cuestión. Esta, la cruz de buena parte de la patrística. También, durante algunos años, de san Agustín.

Bastantes escritores aportaron diferentes hipótesis para resolver el problema. La pregunta quedaba formulada en hexamerones y comentarios a los primeros libros de la biblia, donde alcanzaba especial relieve un muestrario antropológico digno de posteriores aclaraciones teológicas: creación del cosmos y del hombre, pecado, elevación, propagación, resurrección, cuestiones en suma de cosmogénesis y antropogénesis, de protología y escatología. Era por consiguiente imprescindible e inevitable incluir en libros de tal naturaleza la exégesis de Gen $1,28^{4}$. Y como la exégesis fluye condicionada, se quiera o no, por teorías, creencias, mentalidades y formas de pensar de raíz filosófica, mistérica, hasta religioso-cultural habrá que tener en cuenta tales circunstancias, dado que las interpretaciones patrísticas que expondremos son de variado matiz.

Más tarde vendrá ex profeso el Obispo de Hipona, pero adelantemos que todavía por el 401 persiste como problema, en él, la interpretación patrística hasta entonces dada en Gen 1,28. Así lo refiere cuando se pregunta «de dónde hubiera podido provenir la prole de los primeros hombres, que Dios bendijo diciéndoles: Creced y multiplicaos y henchid los confines de la tierra, si nuestros primeros padres no hubiesen pecado" ${ }^{5}$. Y a renglón seguido responde así de sugeridor: «Sobre esta cuestión se han pronunciado múltiples y contrapuestas sentencias. Si hubieran de ser contrastadas para deducir cuál de ellas se

CSEL 28/1,276); De sancta virginit. 1,1 (PL 40,397, CSEL 41,235); De pecc. mer. remis. I, 29,57 (PL 44,142), CSEL 60,56); De bono vid. 15,19 (PL 40,442, CSEL 41,326); De pecc. orig. 34,39 (PL 44,404, CSEL 42,197).

3. Cf. De bono coniug. 2,2 (PL 40,373, CSEL 41,188). R. Flórez, Presencia de la verdad. Prólogo A. Muñoz Alonso, Madrid 1971, 126.257; V. Grossi, L'antropologia agostiniana. Note previe, Augustinianum 22 (1982) 457-467.

4. Cf. F.-ThonNARD, La morale conjugale selon saint Augustin, REAug 15 (1969) 113-131: 115-117. Para la exégesis en los Padres ver el reciente estudio de M. Simonetti, Profilo storico dell'esegesi patristica. Istituto Patristico Augustianum, Roma 1981.

5. Cf. De bono coniug. 2,2 (BAC 121,43). 
conforma más adecuadamente con la verdad de las divinas Escrituras, darían materia de prolija y ardua disputación» ${ }^{6}$.

«Múltiples y contrapuestas sentencias» («Plures... sentenciae diversaeque»). A cuáles eran éstas y en qué consistían responde también, y en síntesis, el propio santo. Aduce tres: $1^{\text {a }}$ ) Multiplicación real, pero sin comercio de la carne: «De no haber prevaricado la primera progenie humana, hubiéranse podido engendrar los hijos con cualquier otro arbitrio fuera del comercio carnal» ${ }^{7} .2^{\text {a }}$ ) Multiplicación mística: "Quizá sea que en el referido pasaje se quieran expresar muchas otras cosas en un sentido místico y figurado, y haya que interpretar la frase Henchid la tierra y sometedla a vuestro dominio de forma que la refiramos a la plenitud y perfección de la vida y del poder, del mismo modo que el incremento y la multiplicación, cuando se dice: Creced y multiplicaos, pueden entenderse del crecimiento de la inteligencia y de la abundancia de las virtudes» ${ }^{8} .3^{\text {a }}$ ) Multiplicación real por comercio de la carne, pero sin concupiscencia desordenada: «Quizá, en fin, a los primeros padres les hubiera sido otorgado en un principio un cuerpo no espiritual, sino animal, a fin de que por el mérito y retribución de su obediencia ese cuerpo fuera tornándose espiritual y digno de conseguir la inmortalidad, no después de la muerte..., sino por aquella transmutación de que habla el Apóstol..., para que entendamos que los cuerpos de aquel primer matrimonio, en su primigenia conformación, fueron creados en un estado de mortalidad ciertamente $y$, no obstante, de no pecar, no hubieran estado sujetos a la muerte con que el Señor les conminó... hubieran podido subsistir y prolongarse las generaciones por la unión conyugal de esos cuerpos primeramente formados» ${ }^{9}$. Dejemos los pormenores para más adelante. De momento importa saber que san Agustín no revela la paternidad de tales sentencias. Tampoco en De sancta virginitate lo hará con las posturas encontradas respecto del matrimonio y la virginidad ${ }^{10}$. Así que lo primero que procede es individuar a los autores ocultos tras el desdibujado y genérico plures, y dar con sus raíces. No será difícil entonces conocer los respectivos influjos y nexos religioso-culturales en los

6. Ib., 2,2 (col. 374, p. 188): «Plures enim de hac re sententiae diversaeque exstiterunt; et si examinandum sit, veritati divinarum Scripturarum quaenam earum potissimum congruat, prolixae disputationis negotium est" (BAC 121,43). Ello no quita para que san Agustín, como cualquier cristiano de los primeros tiempos, estuviera convencido de la transformación obrada por Cristo en las cosas, el matrimonio una de ellas. Cf. R.-C. GEREST, Mistero e problemi del matrimonio nei primi cinque secoli della Chiesa, SacDot 13 (1968) 19-59: 19ss.

7. Ibid. 2,2 .

8. Ibid. 2,2 .

9. Ibid. 2,2.

10. Cf. P. LANGA, Equilibrio agustiniano entre matrimonio y virginidad, RA 21 (1980) 73134. 
que se apoyan las distintas sentencias patrísticas con que san Agustín se tropieza y enuncia, estudia y sigue, o, llegado el caso, corrige y supera.

\section{PREsupuestos Motivadores DE TALES SENTENCIAS}

1. Escuelas de Alejandría y Antioquía. Alejandría fue la primera y más importante de las dos, el más antiguo centro de ciencias sagradas en la historia del cristianismo. Agrupó a los grandes maestros Clemente, Pierio, Dionisio, Atanasio, Dídimo, Cirilo, y desde luego la figura estelar Orígenes. Pronta a la investigación metafísica del contenido de la fe, de tendencia preferentemente especulativa, intuitiva, mística y, por ello, casi siempre conforme con las elevaciones contemplativas del platonismo. Sin desechar el literal, sus pensadores adoptaron el método alegórico, convencidos como estaban de que el literal. era, a menudo, indigno de Dios. Contribuyó a resolver el gran problema de la Iglesia primitiva: la interpretación del AT ${ }^{11}$.

Contrapunto suyo en algunas cosas, vino después la antioquena, inclinada por la realidad, la práctica, la lógica, para lo que no vaciló en admitir un eclecticismo más o menos acusado y cercano al estoicismo. Sus preferencias fueron aristotélicas. Destacan dentro de sus filas Diodoro de Tarso, Teodoreto de Ciro, san Juan Crisóstomo y Teodoro de Mopsuestia. Sin embargo, conviene precisar: primero, que la antioquena no es, propiamente hablando, escuela, pues nunca se lo propuso a la manera de Alejandría, sede eclesiástica con teología inconfundible y exégesis definida; segundo, que la hermeneútica de los principales antioquenos demuestra que la contraposición exegética entre las dos escuelas, tan arraigada por ahí, resulta inexacta, pues ambas arrancan de la unidad habida entre A y NT, y una y otra comparten asimismo el sentido literal como punto de partida de cualquier exégesis, y luego la trascendencia - en modo alguno sustitución - del literal a otro superior. Difieren en que la exégesis alejandrina propende a dicha trascendecia en tanto que la antioquena, a menudo por reacción antialejandrina, carece de ese fervor ${ }^{12}$. No

11. Cf. A. DE LA BARRE, «Alexandrie» (École chrétienne d'), DThC 1, (Paris 1902) 805-824: 812-816; G. BARDY, Aux origines de l'école d'Alexandrie, RSR 27 (1937) 65-90; H. RAHNER, Alexandrinische Schule, LThK I ${ }^{2}$, 323-25; J. QUASTEN, Patrología I, BAC 206, Madrid ${ }^{2} 1968,317-$ 19;J.N.D. Kelly, Early Christian Doctrines, London ${ }^{4} 1968,69-75$; Q. SKRZYPEZAK, Alejandría, Escuela exegética de, EBib. I, 306-307.

12. Cf. A. VACCARI, La «Theoría» nella scuola esegetica d'Antiochia, Bib. 1 (1920) 3-36; V. EERMONI, "Antioche» (École théologique d'), DthC 2 (Paris 1923) 1435-1439; E. AMANN, Théodore de Mopsueste, DThC 29 (Paris 1946) 235-279: 248.277; H. DE LuBAC «Thypologie» et «allegorisme», RSR 34 (1947) 180-226; J. GuILLET, Les exégèses d'Alexandrie et d'Antiochie, conflict ou malentendu?, RSR 34 (1947) 257-302; J. QUASTEN, Patrología I, BAC 206, Madrid 
hay duda de que al alegorismo exegético demasiadas veces extremista de los alejandrinos se opuso temperándolo el literalismo de los antioquenos. Esto hay que saberlo, porque en las sentencias subsiguientes, por lo menos al principio, abunda lo alejandrino por más que, andando el tiempo, se deje también sentir lo antioqueno.

2. A imagen y semejanza de Dios. Es clásica de tan sabida la diferencia entre los dos relatos genesiacos de la creación del hombre. El Código Sacerdotal (P), de hacia el 500 a.C., con fuerte unidad literal (Gen 1,1.2,4a), precisa la fe del autor sagrado en la creación universal: todo surge del poder creador de la Palabra de Dios que, al sacar de la nada el universo (cielo y tierra), hace otro tanto con el tiempo (los siete días de la semana). El Yahwista (J) en cambio, del siglo $\mathrm{x}$ a.C., con sicología envidiable y sorprendente capacidad descriptiva intenta responder de manera extraordinariamente simple a los problemas candentes del hombre y de su historia (Gen 2,7-9.16-25). Para la creación del hombre, leemos en Gen 1,27: Et creavit hominem ad imaginem suam, mientras la frase de Gen 2,7 es: Formavit igitur Dominus Deus hominem de limo terrae.

El tema central de la antropología de los Padres se reduce al estudio de los términos imagen (eikon) y semejanza (omoiosis) ${ }^{13}$. Inicialmente se impone distinguir la problemática del Verbo de la de las criaturas en cuanto imagen de Dios. Esta última se apoya en la primera, pero la distinción es fundamental, so pena de confundir cristología y antropología. La vertiente antropológica de la imagen de Dios es rica de contenido: imagen y gracia, imagen y sexo, imagen y caída original, imagen y sus relaciones con la semejanza. Los Padres de los siglos III y IV dependen en este asunto, por cuanto dice a la idea y seguro respecto a vocabulario, principalmente de tres fuentes: bíblica, filosófica y patrística anterior.

En punto a fuentes bíblicas Gen 1,26-27 es básico. Y que pertenezca al

\footnotetext{
${ }^{2} 1968$, 429s.; H. RAHNER, Antiochenische Schule, LThK I², 650-52; Q. SKrzYPEZAK, Antioquía, Escuela exegética de, EBib. I, 551s.; J.N.D. KELLY, 75-78; Ch. SCHÄUBLIN, Untersuchungen zur Methode u.Herkunft der antioch. Schule, Köln-Bonn 1974; B. DE MARGERIE Introduction à l'histoire de l'exégèse. I, Les Pères grecs et orientaux, Paris 1980 188-213. M. SimonetTi, Profilo..., 113-127, cf. Augustinianum 22 (1982) 605s.

13. Cf. J. Gross, La divinisation du chrétien d'après les Pères grecs. Contribution à la doctrine de la grâce, Paris 1938; F.W. ElTESTER, Eikôn im Neuen Testament, Berlin 1958; J. JERvell, Imago Dei. Gen. 1,26f. im Spätjudentum, in der Gonisis und in den paulinischen Briefen, Göttingen 1960; J. KIRCHMEYER, Brecque (Église): L'image et la ressemblance, DSp 6 (1967) 813 822.840-841 (bibli.); VI. LossKy, La teologia mistica della Chiesa d'Oriente, Bologna 1967, 105 125; P. LAMARCHE, Image et ressemblance dans l'Écriture Sainte, DSp 7/2 (1971) 1402-1406; Th. SPIDLIK, La spiritualité de l'Orient chrétien, Roma 1978, 53-83:53-61 (bibl. espec.: 349-350).
} 
Sacerdotal (P) hace presumir en todo él una elaboración teológica ${ }^{14}$ entre cuyas finalidades precisas está la de humillar al hombre con objeto de que por ello destaque más la trascendencia de Yavé. Así y todo, Gen 1,26-27 ve en Dios el origen, la naturaleza y la fecundidad del hombre, al tiempo que representa un punto avanzado de la antropología del AT.

Por lo que atañe a las filosóficas, digamos que el tema de la imagen, de la parentela, de la semejanza tiene raíces platónicas y estoicas, es muy probable que dimane de religiones astrales de origen irano-caldeo, y no hay que desdeñar tampoco vestigios del gnosticismo. Los Padres, cierto, afirman lo de la imagen sobre la Escritura, pero desarrollando a la vez materiales valiosos suministrados por la filosofía griega. Platón estudia el mundo invisible usando a menudo la palabra eikon, lo mismo que suggeneia y oieikosis. Es así como él expresa la relación del alma con el mundo divino de las ideas ${ }^{15}$. Su pensamiento está dominado por dos antítesis: espíritu-materia y ser-devenir ${ }^{16}$. La filosofía con empuje durante los dos primeros siglos del cristianismo es ecléctica de lo platónico y estoico. El estoicismo es optimista: colocado en el mundo, el hombre está llamado y ordenado a colaborar con la razón universal. El platonismo, a la inversa, pesimista: la venida del alma a este mundo comprende una caída en el mundo de la materia. Y, en fin, el medio platonismo habla de lo que se ha dado en llamar «tríada platónica». Doctrinas helénicas éstas, después de todo, que, aplicadas a la especulación bíblica, requerirán adaptaciones oportunas y acomodos que, según sean materiales o formales, así redundarán en pesimismo mayor o menor de la teología patrística ${ }^{17}$.

En cuanto a la primera tradición cristiana hay que destacar, por último, que la importancia de Gen 1,26-27 es particularmente relevante en los escritos paulinos ${ }^{18}$. En el NT concurren tres elementos: semejanza, dependencia y ma-

14. Gen 1,26-27 ha de ser comparado con Gen 2,7 para su adecuado entendimiento. La afirmación del relato $P$. o Sacerdotal (Gen 1,26-27) toma posición tanto contra los teomorfismos de Egipto como frente a las tendencias panteístas de los mitos babilónicos. Y mientras eikon tiene sentido concreto de imagen plástica (la imagen erguida, expresión del poder espiritual del hombre), omoiosis excluye el antropomorfismo y propone el monoteísmo. Cf. Th. SPIDLik, 54.

15. Cf. Tim. 92; Fedón 79; Leyes IV, 716; Rep. IV, 490.

16. Según Platón la realidad en sí es el «mundo del Ser inmutable», que merece el nombre de Dios. El alma (nous) es inmortal, pero el contacto con el cuerpo hace que viva con nostalgia del mundo superior. Por otra parte, solamente admite una «unión accidental» entre el alma y el cuerpo. El alma tiende a retornar al mundo de las ideas mediante la purificación y la imitación del mundo astral.

17. La relación modelo-imagen se establece por grados sucesivos: Primer Dios y Demiurgo, Demiurgo y mundo, etc. Sólo el alma, salida del primer Dios, es imagen de Dios. Ciertamente la «tríada» influye en los Padres a la hora de hablar sobre la Trinidad, de ahi que tiendan siempre a un subordinacionismo. Para los puntos sobre los cuales insisten los Padres o precisan de la pertinente adaptación cristiana, cf. Th. SPIDLik, 55-61.

18. Cf. A. Feuillet, Le Christ, sagesse de Dieu d'après des epitres pauliniennes, Paris 
nifestación. De ahí que lo trabajen ya los primeros escritores cristianos. Si la creación del hombre a imagen y semejanza de Dios jamás fue asunto contestado, su quid cuenta, por el contrario, con muy rica variedad de opiniones. El estoicismo pesa no poco en Clemente de Alejandría, y sobre idéntico argumento digamos de igual manera que el Pseudobernabé se sitúa dentro del movimiento alejandrino influenciado de Filón. Teófilo de Antioquía, por su parte, interpreta Gen 1,26-27 en clave trinitaria: el Hijo y el Espiritu Santo colaboran a la obra del Padre. La teología antioquena describe el bautismo como un retorno al paraíso. He ahí una de las causas que vinculan al bautismo con el Génesis. La semejanza consiste en la disposición y vocación de todo el hombre a participar de la inmortalidad de Dios. Ahora bien, esta favorable actitud da un poder virtual, pues está sometido el hombre a la prueba de la fidelidad y del progreso. El hombre es un ser intermedio, ni inmortal ni mortal, sino capaz de ambas cosas. En los autores mencionados se empieza a notar ya la diferencia entre la imagen y semejanza. La cuestión sería muy larga de quererla tratar por menudo y, por otra parte, ha de salir, siquiera sea de forma tangencial o indirecta, acompañando a los grandes Padres griegos. Quede aquí, pues, sólo como pura constatación ${ }^{19}$.

3. La doble creación. La divergencia entre creavit $(\mathrm{P})$ y formavit $(\mathrm{J})$ dio pie a lo largo de la patrística, la griega sobre todo, a la corriente de la célebre doble creación, con el bagaje de lógicas consecuencias, peculiaridades y enfoques propios. "Típico tema antropológico» al decir de U. Bianchi ${ }^{20}$, la doble creación procede de las antropologías dualistas, la etnología, la misteriosofía y el gnosticismo. Por definición es doble, conforme el protagonismo sea plural o singular. En la primera, Dios, o el gran Demiurgo platónico, efectúa la creación auxiliado de colaboradores - nunca rivales- que le sirven de intermediarios, llámense éstos dioses gennetoi del Timeo, potencias de Filón, o ángeles de algunas haireseis judaicas, y que son los encargados de crear el cuerpo o las partes inferiores del alma, aquello a fin de cuentas de lo que puede surgir el mal. En la segunda, es Dios solo quien lleva a cabo la acción creadora, pero en dos fases y con verdadera contraposición - no sólo distinción- de valores entre el objeto de la primera y el de la segunda. Más aún: entre ambas creacio-

1965. San Pablo usa eikon tanto para Cristo como para el hombre. En la predicación apostólica encontramos que el tema de la semejanza aparece en el kerygma lo mismo que en la catequesis bautismal (2Cor 3,18; 4,4; Col 1,15).

19. Para un estudio sumario del argumento, con bibliografía y fuentes, cf. Th. SPIDLí, 5383 (bibl. 340-412, espec. 349-350.391).

20. Cf. U. BiANCHI, La 'doppia creazione' dell'uomo come oggetto di ricerca storicoreligiosa, DCU 1-23: 3. 
nes, de una u otra fase para entendernos, puede haber a la par distancia cronológica o simplemente ontológica.

Aquí nos interesa la doble creación de protagonismo singular, con sus matices propios, dualismo comprendido, entendiendo, eso sí, que no se trata del filosófico de tipo tradicional, producto de la oposición trascendenciainmanencia, o monismo panteístico, sino de los llamados dualismos primitivos, o sea, de la «dottrina dei due principii (archai) che - coeterni o no- fondano l'esistenza di ciò che esiste o si manifesta nel mondo» ${ }^{21}$.

Por cuanto a varón y hembra concierne, es fácil reparar que mientras el Yahwista incide sobre los derechos de igualdad entre uno y otra, sin mencionar de modo preciso la procreación, el Sacerdotal, por el contrario, silencia este amor recíproco de la pareja para destacar antes que nada la procreación bendecida por Dios. Nótese bien que es en el Sacerdotal donde figura crescite et multiplicamini (Gen 1,28) ${ }^{22}$. Varón y hembra, creced y multiplicaos son, pues, temáticas fundamentales de la corporeidad, la cual a su vez lo es de la más amplia y ya mencionada doble creación. He aquí, pues, el campo por donde discurre la exégesis patrística que expondremos, aunque aún falta otro preámbulo:

4. Raíces religiosas y culturales. La inclinación inicial de quienes van a comparecer es alegórica, o sea teñida de colorido alejandrino más que nada, extraña por tanto a la mentalidad antropológica de un Ireneo, por ejemplo ${ }^{23}$. Análisis cronológico-temático adelante, sin embargo, se advierte cada vez mejor cómo por la simpatía alegórico-alejandrina se va filtrando poco a poco lo antioqueno. De modo que la multiplicación asexual se propugnará no ya sólo desde un alegorismo más o menos acentuado, sino además, y sobre todo, por razones pastorales, el culto a la virginidad la que más. La depravación contribuye a radicalizar posturas contrarias a la materia, a que se mire la carne, el matrimonio, el sexo con prejuicios de los que tampoco escapa la interpretación de crescite et multiplicamini ${ }^{24}$. Unos y otros en todo caso, y esto es de suma importancia, acusan en sus esquemas platonismo y ontología griega.

21. Cf. U. BIANCHI, DCU 6.

22. Cf. R. TreviJANo, Matrimonio y divorcio en la Sagrada Escritura, en: AA.VV., El vínculo matrimonial. ¿Divorcio o indisolubilidad?, BAC 395, Madrid 1978, 3-59: 7-9; S. AuSIN, Matrimonio y designio de Dios. Anotaciones exegéticas a Gen 2,4-25, en: AA.VV., Cuestiones fundamentales sobre matrimonio y Familia. II Simposio Internacional de Teología. Universidad de Navarra, Pamplona 1980, 133-148.

23. Para un estudio de esta línea de san Ireneo, cf. A. ORBE, Antropología de S. Ireneo, BAC 286, Madrid 1969, 6ss. Para la dimensión exegética del Santo, cf. B. DE MARgerie, 64-94.

24. El platonismo marcó en Orígenes una huella perceptible a través de numerosos argumentos. Por ejemplo, ese considerar indigna de Dios la creación de un hombre corpóreo antes del 
El encratismo de motivaciones ontológicas y protológicas, dicho sea de paso, arraiga en concepciones antropológicas de tipo platónico, es decir en el concepto dualista de la persona humana. Y esto es comprobable en Filón de Alejandría, Orígenes, con buena lista de seguidores. El problema se agrava cuando se recurre a esta dialéctica platónica tipo dualista para expresar categorías inspiradas en la religión mosaica. Es evidente que dentro de un cuadro bíblico, la cuestión del cuerpo viene a constituir con la mencionada dialéctica un elemento nuevo al que distintas posiciones cristianas tratarán de dar solución con diversos enfoques propios de sus respectivas mentalidades, desde el docetismo de los valentinianos a los conceptos encratistas moderados de Orígenes, desde los Capadocios a tantos autores de fechas tardías, incluso posteriores a san Agustín.

Hay que saber, además que la problemática enunciada implica, según la corriente patrística en examen, la doctrina de la doble creación, en la cual la segunda, es a saber, la del hombre con corporeidad densa, pesante, grosera, oscila entre el relato de Gen 2 (hombre modelado) y Gen 3 (el de las túnicas de piel). La primera corresponde a Gen 1,26ss. Lo grave aquí -también lo que interesa - es cuanto de tal diferencia se concluye. Nada menos que esto: la existencia del cuerpo que funciona fisiológicamente, del cuerpo sexuado en otras palabras, del ejercicio de la sexualidad para decirlo más completo, está condicionada por causa del pecado primordial. Sobre tales doctrinas dualistas de línea encratista, platónica y hasta gnóstica grava, pues, la pesada y oscura tesitura según la cual el primer pecado del hombre habría determinado estas intervenciones «segundas» de Dios. La sexualidad, así, será negativamente enjuiciada - «condenada»- no por su inexistencia inicial, al menos no sólo por eso, sino antes que nada por considerarla fruto del primer pecado.

También la virginidad de Adán encuentra fundamentos ontológicos y protológicos a lo largo de la tradición patrística, de esa corriente eclesiástica que define el matrimonio como institución postlapsaria y consecuencia de una caída, por más que dicho efecto sea querido, en cuanto previsto, por Dios. Qué duda cabe de que las nupcias reciben también en clave platónica trato positivo. Más común, sin embargo, será lo contrario ${ }^{25}$. Desde el punto de vista de

pecado (A. Orbe, 25). Y, por medio de Orígenes, pasó a toda una corriente posterior, a la que se opuso el contrapeso pastoral de los antioquenos, muy dados a la problemática de la virginidad de Adán y, en consecuencia, también contagiados de prejuicios antisexuales. Verlo más o menos acentuado por gran parte de los colaboradores en ATs, DCU y por Paola Pisi.

25. Cf. Paola PISI, 95-100. Y, en general, toda la segunda parte de la obra, titulada: Le motivazioni protologiche della verginita: Excursus sui Padri contemporanei e predecessori di Gregorio di Nissa. Ver también Pier F. BEATRICE, Continenza e matrimonio nel cristianesimo primitivo, SPM 3-68. 
estos dualismos parece lógico que la interpretación de: crescite et multiplicamini resulte muy difícil por la vía literal. Con habilidad entonces, a través de la exégesis alegórica o desde presupuestos de la virginidad paradisíaca, los $\mathrm{Pa}$ dres y autores antiguos, algunos, aportarán las más curiosas soluciones para resolver el problema del multiplicaos antelapsario.

\section{LAS SENTENCIAS PATRÍSTICAS}

\section{1) Filón de Alejandría (30 a.C.-50 d.C.)}

Para bastantes argumentos, el que nos ocupa es uno, constituye la cabeza de puente del platonismo a la patrística. A tres cabría reducir los motivos que le atraen a la lista: exégesis alegórica, doctrina antropológica, e influjo helenístico. Vamos a verlo.

1:1. Exégesis alegórica. En rigor Filón no es el padre de la exégesis alegórica ${ }^{26}$ dado que había sido patrimonio de naturalistas y estoicos ${ }^{27}$ y que, como precursores inmediatos, afines casi, la historia registra al filósofo judeoalejandrino Aristóbulo (ca. 170-120 a.C.), de cuya exégesis Clemente de Alejandría se hará eco en Strom. V, 14,97, y al Pseudoaristeas (120-90 a.C.) cuando éste escriba a Filóstratos ${ }^{28}$. Filón por otra parte quedaría desdibujado de excluir en él la hermenéutica del judaísmo palestinense, lo mismo rabínica que qumránica ${ }^{29}$. Sí es el primero en servirse de ella para la biblia echando

26. Para la exégesis alegórica en Filón, cf. E. BREHIER, Les idées philosophiques et religieuses de Philon d'Alexandrie, Paris 1925, 37-66; E. STEIN, Die allegorische Exegese des Philo aus Alexandria (BZAW 51), Giessen 1929; H.A. Wolfson, Philo, Cambridge/Massachusetts 1948, vol. 2, 115-138; D. Daniélou, Philon d'Alexandrie, Paris 1958, 119-142; J. PePIN, Remarques sur la théorie de l'exégese allégorique chez Philon, en: AA.VV., Philon d'Alexandrie, Paris 1967, 131-150; P. BoyAwCE; Écho des exégèses de la mythologie greque ches Philon, en: Philon d'Alexandrie, 169-186; I. CHRISTIANSEN, Die Tecnik der allegorischen Auslegungswissenschaft bei Philon von Alexandrien, Tübingen 1969; G. Delling, Wunder-Allegorie-Mythus bei Philon von Alexandria, en: AA.VV., Studien zum Neuen Testament und zum Hellenistischen Judentum, Göttingen 1970, 72-129; A. MADDALENA, Filone alessandrino, Milano 1970, 9-20; B. DE MARGERIE, 12 22 .

27. Los naturalistas con el fin de quedar respaldados por Homero (Ilíada y Odisea) en la defensa de las teorías filosóficas del origen cósmico. Los de la Stoa, para conciliar desde Homero también sus irreverentes asertos de los dioses. la obra de Heráclito, filósofo estoico del siglo I a.C., con su frecuente interpretación alegórica de Homero, suministra abundante luz al método alegórico del estoicismo (Heráclito, Allegor. Homeric, éd. F. Buffiére, Paris 1962).

28. Cf. la éd. de A. Peletier, SCh 89 (Paris 1962) parágr. 144-171. Por otra parte, las mismas obras filonianas reflejan claro el profundo conocimiento de su autor acerca de las corrientes filosófica del tiempo, el platonismo de manera especial.

29. Los dos centros de instrucción religiosa en el judaísmo rabínico eran la escuela y la sina- 
mano de principios filosóficos griegos. Dicha exégesis discurría por aquellas fechas estrechamente unida a las teorías místicas de los neopitagóricos, de los órficos, y de los sacerdotes egipcianos. Los primeros en utilizarla habían de ser los judíos más cercanos a la civilización de la Hélade. Filón integraba el grupo y sus ideas ganaron la Escuela Alejandrina, donde la alegoría cobró significación histórica ${ }^{30}$. Cierto que la suya fue cultura judaica más que griega ${ }^{31}$, pero justo es reconocer también con Bréhier que las causas de la transformación del espíritu griego, para nuestro judeoalejandrino, lejos de acudir a su indiscutible judaísmo, hay que situarlas más bien en el ambiente de Alejandría, de suerte que «c'est là, sous influences multiples et obscures, que s'est accomplie cette fusion entre philosophie et révélation d'où est sorti le philonisme» ${ }^{32}$.

1:2. Doctrina antropológica. Las cuestiones de protología y escatología necesitan de la corporeidad para su adecuado enfoque antropológico. Así lo entendió nuestro autor, que hubo de enfrentarse a un dogmatismo ateo de resonancias peripatéticas y epicureístas, entonces dominante, desde el escepticismo griego de años atrás ${ }^{33}$, aunque por brillo fue siempre platónico. De hecho, cuando describe la formación del mundo recurre a fórmulas platónicas, y más aún estoicas ${ }^{34}$.

Los relatos genesiacos de la creación del hombre no son, a su entender, maneras diferentes de referir un mismo hecho, sino pasajes que miran a dos creaciones distintas ${ }^{35}$. Creado a imagen y semejanza de Dios - kat'eikona Theoù kai kat'omoíoin (Gen 1,26) - está bien dicho - precisa- en cuanto

goga. Una y otra usaban la exégesis midrásica, en la escuela (explicación de las partes históricas de la Torah) denominada Midrás halákico, mientras en la sinagoga (explicación de las partes históricas y éticas del AT), Midrás aggádico. Para los métodos hermenéuticos de la exégesis midrásica (literal, dialéctico, filológico, alegórico), cf. J. BonsIRVEN, Exégèse Rabbinique et Exégèse Paulinienne, Paris 1939, 83-115; E. STEIN, Philo und der Midrasch. Philos Schildernug der Gestalten des Pentateuch verglichen mit der des Midrasch (VZAW 57), Giessen 1931. La exégesis qumránica acaba a menudo en un alegorismo subjetivo y arbitrario: cf. S.H. Hoo, Symbolism in the Dead Sea Scrools, StEv 1 (TU 73), Berlin 1959, 600-612. 61.

30. Cf. G. BARdy, Philon le Juif, DThC 23 (Paris 1933) 1439-1456: 1444-1448; E. BreHIER,

31. Además de que Filón conocía el platonismo, adviértase que cuando en Palestina aparece el movimiento cristiano, Alejandría ha sido y continúa siendo importante centro de la comunidad judaica. El Pseudoaristeas deja asimismo claro que hacia los ss. III-II a.C., el estudio de la Escritura tenía ya un puesto de mucho relieve.

32. Cf. E. BREHIER, 317:

33. Cf. E. BREHIER, 84-114.207-225.

34. Cf. E. BrEhIER, 78-82.

35. Que Filón comente el Génesis en Leg. sólo a partir del c. 2 ha dado pie a suponer otro comentario alegórico del c. 1, paralelo al Opif., hoy perdido. La suposición cuenta con impugnadores (L. Cohn, Die Werke Philos von Alexandreia, III, Teil, Breslau 1919, 9) y defensores (E. 
que nadie ha surgido de la tierra que se asemeje más a Dios que el hombre; pero que tampoco se interprete esta semejanza a través del cuerpo, porque ni Dios tiene figura humana ni el cuerpo humano forma de Dios ${ }^{36}$. Distingue al hombre celeste (ouránios) del terrestre (géînos), al de la primera del de la segunda creación, entre el ideal que Dios hizo (epóiesen) y el terrestre por Dios formado (éplasen) ${ }^{37}$, ajeno aquí al celeste-terrestre o interior-exterior de san Pablo ${ }^{38}$. A dar este paso se arriesgará posteriormente Orígenes ${ }^{39}$. Correspondiendo a la doble creación del hombre, plenamente admitida, aparecen el cuerpo celeste y el cuerpo terrestre ${ }^{40}$. Filón describe el terrestre con imágenes platónicas: templo, prisión, cadáver, tumba, en nada similar a Dios por la razón apuntada y distinto, además, del anthropos intelectual de la primera creación, incorpóreo él, incorruptible, ni varón ni hembra, dotado a lo sumo de cuerpo etéreo, luminoso, espiritual, pero al estilo gnóstico no paulino ${ }^{41}$.

Así las cosas, resulta dificilísimo compaginar con la economía redentiva

BréhIER, pp. I-IV). Cf. F. Petit, L'ancienne version latine des questions sur la Genèse de Philon d'Alexandrie, I, Berlin 1973, pp. VII. 1ss.

36. Cf. Opif. 69; Confs. 41.147. Al respecto cf. A. SLOMKowsKi, L'état primitif de l'homme dans la Tradition de l'église avant Augustin, Paris 1928, 11-16; A. HaMmaN, L'enseignement patristique sur la création, RevSR 42 (1968) 1-23; 97-122: 105-108; J. DANIÉlou, Philon d'Alexandrie, 173; Paola PISI, 182-194 (con bibl.).

37. Cf. Leg. I, 31-42; Opif. 76.134. para las dificultades de la antropología filoniana y juicios críticos acerca del Opif. cf. R. ARNALdEz, «Les Oeuvres de Philon d'Alexandrie». Introduction Generale. «De opoficio mundi», 1, Paris 1961, 17-112: 17ss.; A. OrBE, 8ss. Cf. también a A.M. MAZZANTI, L'aggettivo «methórios» e la doppia creazione dell'uomo in filone di Laessandria, en: DCU 25-42; R.A. BAER, Philo's Use of the Categories Male and Female, London 1970, 65.20-34; G. REALE, Filone di Alessandria, La creazione del mondo. Le allegorie delle leggi, Milano 1978, 51; Paola PISI, 182-185.

38. En 1Cor 15,47 - donde el Apóstol diferencia a un primer hombre (ó prótos ánthropos) hecho de la tierra, terreno, de un segundo hombre ( $\delta$ déuteros ánthropos) proveniente del cielo ékx oúranoú)- Pablo sitúa como punto de apoyo el hecho todo de la resurrección de Cristo. Filón en cambio se mueve, más bien, en el terreno de las dos creaciones genesíacas. Tampoco tiene que ver aquí con la línea paulina de 2 Cor 4,16 .

39. «La doble creación filoniana pasó en buena parte a Orígenes, donde revistió elementos singularmente paulinos -escribe el P. Orbe-. El binomio de hombres ideal y corpóreo - prosigue - convirtióse en el hombre interior y exterior. Era obvio explicar a Moisés por Pablo. Orígenes perfiló más decididamente el contraste factus-plasmatus, amontonando sobre el primero las cualidades platónicas del intelecto (noús) y las paulinas del espiritual (pneumatikós), celeste (epouránios), nuevo (kainós); y sobre el segundo, las categorias comunes al hombre sensible (aísthetós) y material del platonismo y al animal (fúxikós), terreno (Xoîkós, géînos), viejo (palaiós)... del Apóstol» (A. Orbe, 10).

40. Cf. G.S. GaSPARro, Doppia creazione e peccato di Adamo nel «Peri Archon» di Origene: Fondamenti biblici e presupposti platonici dell'esegesi origeniana, DCU 43-82: not. 23.63; Paola PISI, 182-183: not. 36. Cf. de Filón, Her. 68.58.155; Spec. I, 340; Praem. 62; Somn. I, 139; Deus, 150; Leg. I, 108.

41. Cf. Opif. 69; Somn. I, 30; Leg. IIII, 161.162.168.179. Ver asimismo H. Crouzel, Théologie de l'image de Dieu chez Origène, Paris 1956, 55; A. ORBE, 9. 
puntos tan importantes como materia, cuerpo, nutrición, sexualidad. Es cierto que Filón no se pronuncia de manera expresa sobre la hipotética modalidad del multiplicamini, con todo, y atendiendo el contexto, parece lógico suponerle inclinado hacia la multiplicación mística o figurada ${ }^{42}$. Da la sensación de aludirla en De opificio mundi cuando se refiere al poder absoluto por Dios puesto en la tierra con vistas a una misteriosa proliferación, sin necesidad de recurrir a los seres creados ya que para Dios todo es posible (pánta gàr Theó dynatá) ${ }^{43}$. O al escribir: «los frutos no sólo servían de alimento para los seres vivientes, sino que eran también medios para la eterna reproducción de seres semejantes a ellos... Dios, de hecho, quiso que la naturaleza se prolongase, volviendo inmortales los «genes» $\mathrm{y}$ haciéndolos partícipes de la eternidad» ${ }^{44}$.

De no menor importancia que la sexualidad es la virginidad. Por las páginas del De opificio mundi el primer pecado se antoja una falta de concupiscencia sexual. La virginidad de Adán, antes de la caída y de la creación de la mujer, no es sólo para nuestro Judeoalejandrino pura constatación bíblica, también aspecto significativo de la integridad de los orígenes. Y si tocante al argumento de la generación espiritual, tan difundido por la espiritualidad de occidente, se le discute la paternidad sólo será desde cierta perspectiva. Ocurre que Filón conecta la generación espiritual no ya con la contemplación a la manera de Platón, sino además con la práctica de la virginidad, que es lo original suyo. Debe quedar claro, en fin, que la doctrina filoniana adolece de un dualismo más o menos intenso, según temas y exégesis ${ }^{45}$.

1:3. Influjo helenístico. Su antropología debe mucho a la ontología platónica, en la que existe detectable un vínculo de las nupcias con la mortalidad. Como remedios de la mortalidad, el matrimonio y el sexo ejercen un papel positivo, por supuesto, pero no por ligados al plan de caída del hombre. Según Platón el sexo aparece mediante segunda intervención divina, después del pecado de algunos hombres que, al vivir en la injusticia, son condenados a nacer en la segunda generación con cuerpo femenino. De igual manera a juicio de Plotino existe un elemento de caída en la sexualidad. Platón, por tanto, llega a Filón con estos argumentos típicos del helenismo.

Que el Judeoalejandrino influyó en la patrística es cosa segura. Lo arduo

42. Cf. Paola Pisi, 129, not. 23.

43. Cf. Opif. 46.

44. Cf. Opif. 136. Ver Paola PISI, 184.

45. Que la idea de la generación espiritual sea original de Filón, o en todo caso derivada de una fuente desconocida llegada a nosotros y conocida por vez primera gracias al Judeoalejandrino lo propugna A.J. FeStugière, La révélation d'Hermès Trismégiste, Etudes Bibliques, 4 vols., Paris 1944, IV, 224. Paola Pisi, por el contrario, sostiene que tal idea filoniana tiene su raíz en el Simposio platónico (Platón, Symp., 212 AB). Cf. Paola PISI, 186-19: 191. 
es dar con la intensidad. El estoicismo y el platonismo se filtran hasta los Padres de la Iglesia a través suyo ${ }^{46}$. Y no se hace difícil ni mucho menos encontrar rastros filonianos en el Pseudobernabé, Justino y el Pseudojustino. Pero donde hay que hacer menor esfuerzo para descubrir sus huellas es en los iniciadores y maestros de la Escuela Alejandrina, y merced por supuesto a la exégesis. Sobre nuestra materia él fue, valga insistir, punto decisivo de paso al ambiente cristiano de temáticas como la sexualidad y la virginidad. Ya él reduce el ejercicio de la sexualidad a la parte baja del hombre y a la vida de caída como consecuencia del principio del placer, y no vacila en considerar la superior, es decir la imagen de Dios, extraña a todo aquello que se refiera o tenga que ver con la sexualidad y la reproducción. Él, por último, relaciona de la manera ya dicha virginidad y generación espiritual. De donde cabe inferir que la corriente alegórica de los autores que propugnan la interpretación mística de crescite et multiplicamini arranca de su doctrina. Y apurando un poco diríase que del enigmático De opificio mundi, $46{ }^{47}$. Orígenes será el eslabón siguiente de la cadena.

\section{ORÍGENES (185-254)}

Por difícil tal vez, la suya es una exégesis que demasiadas veces los autores contemplan con el prisma unilateral del alegorismo, cuando la realidad impone saberla de mayores vuelos ${ }^{48}$. Aquí en todo caso viene por exégeta alegórico filoniano y por su antropología modernamente encratita y platonizada.

2:1. Orígenes y Filón. Daniélou sostiene que Orígenes llegó a un conocimiento directo de la obra filoniana y que la influencia del Judeoalejandrino

46. Cf. P. HeINISCH, Der Einfluss Philos auf die älteste christliche Exegese (Alttestamentliche Abhandlungen I,1-2), Münster I.Westf. 1908; R. Arnou, Platonisme des Pères, DThC 24 (Paris 1935) 2289s.; G. BARdY, 1443.

47. Cf. Paola Pisi, 201.

48. Sobre exégesis origeniana, cf. C. SIEDfgried, Philo von Alexandrien als Ausleger des Alten Testaments, Jena 1875; F. PRAT, Origène, le théologien et l'exégète. La pensée chrétinne. Paris 1907; J. GuILLET, 252-302; H. DE LuBAC, 180-226; Id., Histoire et Esprit. L'intelligence de l'Escriture d'après Origène, Paris 1950; J. DANIÉlou, L'unité des deux Testaments dans l'oeuvre d'Origène, RSR 35 (1948) 27-56; Id., Origène comme exégète de la Bible, StPatr I (TU 63), Berlin 1957, 280-290; J.M.C. CuESTA, Orígenes intérprete de la S. Escritura, Burgos 1956; J. PEPIN, $A$ Propos de l'histoire de l'exégèse allégorique: l'absurdité, signe de l'allégoria, StPatr I (TU 63), Berlin 1957, 395-413; C. HANSON, Allegory and Event: $A$ Study of the sources and significance of Origen's Interprestation of the Bible, London 1958; J.D. WiLKInSON, $A$ Defense of Origenist Allegory, Stpatr VI (TU 81), Berlin 1962, 264-268; H. CROUZEL, La distinction de la «typologie» et de «l'allégorie», BLE 65 (1964) 161-174; Id., Pourquoi refuse-t-il parfois le sens littéral dans ses Homélies sur l'Hexateuque?, BLE 70 (1969) 241-263; M. HARL, Origénè et la sémantique du langage biblique, VigChr 26 (1972) 161-187; B. DE MARGERIE, 113-136. 
fue en su obra considerable ${ }^{49}$. «Si c'est à Philon qu'Origène doit d'avoir compris que le sens littéral n'est pas toujours propre, mais parfois figuré -escribe B. de Margerie - c'est en forçant quelque peu Philon qu'il exprime l'idée que tous les pasages de l'Ecriture ont aussi un sens figuré» ${ }^{50}$. Entre los principios de exégesis filoniana seguidos destaca el espiritual ${ }^{51}$ y la necesidad de buscar dentro de la biblia una alegoría de la moral de costumbres, de la vida. Existen otros, pero basten éstos por ser los que más cerca conciernen. A fuer de explícitos, el segundo recurre por las homilías del Génesis. Por más que el esquema origeniano de la doble creación refleje concomitancias con el filoniano, sus desigualdades son palmarias. Orígenes, por ejemplo, supera la visual filoniana cuando proyecta la distinción entre el hombre de Gen 1,26 y el de Gen 2,7 a un escenario de dimensión cósmica. A ejemplo de Filón y distanciándose de autores cristianos anteriores o contemporáneos, rehúsa admitir, además, que la condición del eikon pueda referirse al cuerpo del hombre o en todo caso al conjunto de sus componentes; sólo cabe entenderlo de la inteligencia ${ }^{52}$.

2:2. Antropología origeniana. Continuadora de algunos elementos filosóficos ajenos ${ }^{53}$, ya está dicho, su doctrina del cuerpo resplandece de ideas propias, bien sobre la doble creación, bien al pretender desmitologizar la Escritura ${ }^{54}$. Al comentar Gen 1,26 despega del sentido literal (secundum spiritualem intelligentiam) ${ }^{55}$. Esto lo confirma el uso in crescendo del verbo hacer: hizo primero el cielo y la tierra (Gen 1,1 ), después los grandes astros (Gen

49. Cf. J. Daniélou, Origène, Paris 1948, 179-190. Para el influjo de Filón en Orígenes, cf. C. Siegfried, 351-362; M. Simonetti, Intr., en: Origène. I Principi, Torino 1968, 56-77. Las mismas citas origenistas lo corroboran. Ver una edición crítica de éstas en F.C. CONYBEARE, Philo about to contemplative Life, Oxford 1895, 229s.

50. Cf. B. DE MARGERIE, 129.

51. Cf. De princ. IV, 2,9 (GGS V, 308ss.); IV, 3,5, p. 331; IV, 3,1; IV, 3,3; In Matth. tom. XIV, 16 (GGS X, 321-323). Cf. J. DANIElou, Origène, 182; R. CADIOU, La jeunesse d'Origène. Histoire de l'École d'Alexandrie au début du troisième siècle. Études de Théologie historique, $\mathrm{Pa}$ ris $1935,51$.

52. Cf. G.S. Gasparro, DCU, 49.57.

53. La de Orígenes, como la de Plutarco, platónicos y pitagóricos, es antropología prevalentemente ecléctica, lo que no quita para que a la hipótesis filosófica de la materia increada, Orígenes oponga ya la fórmula teológica de la creación ex nihilo (ekx ouk ónton tà ónta epoíeses). Ver F. Prat, 68s. y respecto a la filosofía en Orígenes H. Crouzel, Origène et la philosophie, Paris 1962.

54. Cf. H. DE LubaC, Origène. Homélies sur la Genèse, SCh 7 (Paris 1944) (-62; A. SLOMkowski, 51-57; J. Daniélou, Origène comme exégète de la Bible, 284; F. Prat, 133-139; R. CADIOU, 80; J. DUPUIS, «L'Esprit de l'homme». Étude sur l'anthropologie religieuse d'Origène, Paris 1967.

55. Otras veces escribe «secundum spiritalem intellectum», «secundum firmamentum... mentis nostrae», «per allegoriam figurae», o simplemente «per allegoriam». Expresiones similares abundan a lo largo de In Gen. hom. I, 13.14.15.16.17 (GCS VI, 15-22). 
$1,16)$ y, rematándolo todo, al hombre $($ Gen 1,26$)$ a imagen suya. Del a imagen de Dios desprende Orígenes un hombre interior, invisible, incorpóreo, incorruptible, inmortal ${ }^{56}$. ¿Lástima que de la versión origeniana del « $\mathrm{J}$ » queden sólo fragmentos! Hubiera interesado conocerla completa. De cualquier forma, basta lo que resta para vislumbrar que el acento recae sobre el hombre plasmado y cómo predomina el sentido alegórico.

Orígenes prosigue la línea filoniana de la doble creación: dos hombres «superpuestos», el primero hecho (poieín) a imagen de Dios (Gen 1,26); el segundo, modelado (pláttein) del limo (Gen 2,7); ideal y corpóreo ${ }^{57}$. Introduce en el esquema, sin embargo, varias novedades. La primera, convertir el binomio ideal-corpóreo en interior-exterior de san Pablo. La segunda, interponer el pecado entre ambas creaciones, de suerte que a la del hombre esencial o anthropos inocente e indiferenciado seguiría, a consecuencia de una infracción, la del hombre pecador y diferenciado por el cuerpo. La corporeidad pesante y corruptible se origina, siendo así, por causa del primer pecado, del cual el diablo es príncipe y principio (archè) ${ }^{58}$. Satán constituye, por consiguiente, otra desigualdad. No es superfluo advertir de la convivencia de dos esquemas, el cosmológico, donde la transgresión queda expuesta como circunstancia determinante del paso de los seres racionales del inicial estado de beatitud al de culpa, y el exegético, frecuente en las homilías, que supone la oposición paraísomundo, así como interpretar el episodio de la falta de Adán en cuanto figura de la caída de las criaturas intelectuales en la existencia precósmica ${ }^{59}$.

«El bautismo a que sometió Orígenes la doctrina filoniana de la doble creación - concluye el P. Orbe- tuvo dos consecuencias gravísimas: una, en la antropología sobrenatural, y otra, en la angeología ${ }^{60}$. Porque si el anthro-

56. Cf. In Gen. hom. I, 13 (GCS VI, 15). Una vez más, los innegables rastros platónicos, a través de los cuales asoma Filón con todo su contexto interpretativo de Gen 1,26s (cf. Opif. 69).

57. Cf. In Jerm. hom. I, 10 (GCS III, 8s): In Gen. hom. I, 13 (GCS VI, 15); In Matth. tom. XIV, 16 )GCS X, 321s); In Rom. II, 13 (PG 14,913A); In Cant. Cantic. prol. (GCS VIII, 63). En torno al tema de las dos creaciones en Orígenes, cf. G. BürKE, Des Origenes Lehre vom Urstand des Menschen, ZKTh 72 (1950) 28-33. Sobre Gen 2,7 cf. M. SimonetTI, Alcune osservazioni sull'interpretazione origeniana di «Genesi» 2,7 e 3,21, Aevum 36 (1962) 370s; A. ORBE, 8-13; H. Crouzel, Théologie de l'image, 148s; A. HAMmAN, 101-104; Id., L'anthropologie d'Origène: de l'archà au telos, en: ATs 36-50; U. BIANCHI, Addendum I. Origene, Gregorio di Nissa e il platonismo, en: DCU 99-102.

58. Cf. In Joan. XX, 22 (20) (GCS IV, 355); In Jerem. hom. II, 1 (GCS III, 17); In Luc. hom. XXXIX (GCS IX, 219). Ver también a J. SCHERER, Entretien d'Origène avec Héraclide, SCh 67 (Paris 1960) 88. Orígenes llama algunas veces «el terrestre» (ó Xoîkòz) a Satán, por oposición al celeste (ó epouránios), Cristo (outéstin ó Xristos), que vino a restaurar esa imagen de Dios que estaba deteriorada: cf. In Matth. tom. XV, 18 (GCS X, 402).

59. Cf. G.S. GaSParRo, en: DCU 67s.49.57.

60. Cf. A. Orbe, 10 
pos de Gen 1,26s coincide con el hombre interior de 2 Cor 4,16 se abre entonces la perspectiva de un mundo antropológico, con economía propia de Salud, «preliminar a la creación sensible, e independiente de la toda dispensación carnal» ${ }^{61}$. Y si el hombre plasmado de Gen 2,7 coincide con el corpóreo, corruptible, mortal y exterior de san Pablo, conocidas las circunstancias de su aparición (después del pecado), «se impone una antropología sobrenatural aditicia, con una serie de misterios, tales como la encarnación (pasión, muerte y resurrección de Cristo) y la resurrección de la carne, ajenos a la perspectiva inicial» ${ }^{62}$. Lo específico del hombre, según esta herencia platónica que de Filón pasa de la forma antedicha (novedades) a Orígenes y de éste a Hilario, Ambrosio y toda una lista no pequeña, viene entonces a ser el alma. La teología de san Ireneo a propósito de este argumento, lo hemos anticipado arriba, prefirió centrarse sobre el hombre plasmado ${ }^{63}$.

Las consecuencias afectaron también, como es obvio, al análisis origeniano - alegórico sin duda- de crescite et multiplicamini. Por de pronto Orígenes precisa en In Mathh. tom. XIV, 16-17 que el sexo no aparece en cada uno de los relatos con idénticos términos, pues si para la primera creación varón y hembra son los vocablos escritos, en la segunda son hombre y mujer, con la añadidura de que la mujer no figura más que en el segundo capítulo. Pero no queda aquí la cosa. Vuelve a la carga con la primera homilía sobre el Génesis. Explicar literalmente crescite et multiplicamini, o masculus et femina se le hace árido, esto es indudable. De ahí su recurso a la alegoría, que le permite interpretar varón y hembra a través de los elementos constitutivos del hombre interior, el cual ex spiritu et anima constat. Las homilías origenianas del Génesis ofrecen, pues, un análisis literal de varón y hembra: con tales palabras o bien Dios predice a Adán la futura creación de Eva para hacer creíble la bendición crescite et multiplicamini saliendo así al paso de posibles objeciones, o bien da a entender que Dios habría creado todo por cópulas (el cielo y la tierra, el sol y la luna, etc.) ${ }^{64}$. Pero también afronta y trabaja dichos vocablos con la exégesis alegórica refiriéndolos al espíritu y al alma. En el referido comentario a san Mateo la creación varón-hembra es entendida como figura de la unión de Cristo con la Iglesia. Y desde el Cantar de los Cantares distingue la creación de Gen 1,27 de la de Gen 2,7 para concluir que sólo el hombre plasmado (Gen 2,7) conoce el amor sexual ${ }^{65}$.

61. Cf. A. Orbe, 10-13; H. Crouzel, Théologie de l'image, 148ss.

62. Cf. A. Orbe, 10-13; M. Simonetti, Intr., en: Origène. I. Principi, 64-69.

63. Cf. A. Orbe, 12ss. 25; O. Alberti, Problemi di origine in S. Ireneo, Divinitas 11 (1967) 95-116:102ss.

64. Cf. H. Crouzel, Théologie de l'image, 152-153.

65. Cf. In Gen. hom. I, 15 (GCS VI, 19). Ver también Paola Pisi, 129. 
Masculus et femina - prosigue - pueden engendrar con tal que el alma acate sumisa al espíritu: si concordiam inter se habeant et consensum, convenientia inter se ipsa crescunt vel cogitationes utiles ${ }^{66}$. De lo contrario, neque crescere, neque multiplicari legitime dicitur ${ }^{67}$. La alegoría es evidente, y muy marcada. Con los alimentos del paraíso pasa igual: si la letra apunta a la nutrición, la alegoría verá en ellos los afectos carnales, nunca el cuerpo, ya que valdría tanto como pensar a Dios corporalmente, lo que es impío ${ }^{68}$.

Concluyendo, el crescite et multiplicamini, origenianamente entendido, descansa sobre la interpretación espiritualizante-mística, a la que empujan, desde una parte la exégesis alegórica, de otra puede que sobre todo prejuicios más o menos platónicos y desde luego un encratismo atenuado. Con la necesaria excepción de las novedades ya conocidas, se ve que Orígenes continúa a la par que transmite la corriente filoniana.

\section{SAn Atanasio (ca. 295-373)}

Preocupado de predicar sencillo, como buen pastor de almas, antes que de subidas disquisiciones, san Atanasio denuncia los efectos del pecado en la imagen de Dios: las argucias diabólicas fueron la causa de que el hombre olvidara su imagen divina, su poder de contemplación, su kat'eikóna precipitándose hacia la actual condición natural: eis tò katà físin ${ }^{69}$. A Orígenes lo asimila, y le profesará gran simpatía, bien que exenta de servidumbre, lo que hace que ni establezca distinción entre imagen y semejanza ni tampoco le importe ${ }^{70}$, lo cual tampoco significa que en el estudio de la imagen se incline por Ireneo. Prefiere a los alejandrinos. Y gusta de ver al hombre en cuanto imagen divina (kat'eikóna), inmune de gravidez, espiritual, puro ${ }^{71}$.

66. Cf. In Gen. hom. I, 15.

67. Cf. In Gen. hom. I, 15 (GCS VI, 19): «Masculus spiritus dicitur, femina anima potest nuncupari. Haec si concordiam inter se habeant et consensum, convenientia inter se ipsa crescunt et multiplicantur, generantque filios sensus bonos, et intellectus vel cogitationes utiles, per quae repleant terram... Jan vero si anima coniuncta spiritui, atque eius, ut ita dicam, coniugio copulata, declinet aliquando ad corporeas voluptates, sensumque suum in delectationibus carnalibus inclinet... aliquando vero vitiis carnalibus cedat, talis anima, velut adulterio corporis maculata, neque crescere, neque multiplicari legitime dicitur, quoniam quidem filios adulterorum imperfectos Scriptura designat». El texto completo es, pues, bien significativo. Ver también I, 14.16. En Leg. II, 5 Filón interpreta a la mujer = la sensación y las pasiones.

68. Cf. In Gen. hom. I, 13 (GCS VI, 15); De princ. praef. 8; I, 1-5 (GCS V, 14-20).

69. Cf. Orat. III cont. Arian. 38 (PG 26,405B); De Incarnat. 4 (PG 25,104B); Cont. Gentes, 34 (PG 25,68D); 2, col. 5C; 41, col. 84B; 8, col. 16D; De Incarnat. 3 (PG 25,191B); 11,12, 13. Cf. B. DE MARGERIE, 137-164.

70. Sobre la imagen de Dios según san Atanasio, cf. R. BERnARD, L'imagen de Dieu d'après saint Athanase, Paris 1952, espec. 12,25ss.39ss.

71. Cf. Cont. Gentes, 2.3.34 (PG 25,5C-8D.68D); De Incarnat. 43.11 (PG 25, 172BC.116B); R. BERNARD, 29, not. 4. 
Qué opina del creced y multiplicaos no lo dice expresa y claramente. De atenernos a su línea preferida, habría que responder con la interpretación alegórica. A ello conduce su comentario al salmo 50: Ecce enim in iniquitatibus conceptus sum, de donde hace salir que el matrimonio no entraba en los fines iniciales de Dios al crear al hombre, sino que vino luego, una vez cometido el pecado: «El fin principal de Dios ('Epeiè ò proegoúmenos skopós tou Theoú...) era que nosotros existiéramos sin matrimonio y sin corrupción, pero la transgresión del mandamiento introdujo el matrimonio» ${ }^{72}$. Esta valoración crítica la respalda el saber a san Atanasio en tales circunsctancias tributario del platonismo. O sea, que el matrimonio según el campeón de la ortodoxia antiarriana es efecto del primer pecado ${ }^{73}$.

\section{ENTRE SAN BASILIO El GRANDE y BASILIO DE ANCIRA}

Urge decir del primero que comparece debido sólo a la dudosa paternidad de algunas obras menesterosas de atención. Literatura exegética en mano, precisemos que sus homilías del Hexamerón, de un Basilio maduro ya, quedan interrumpidas en el día 5, con lo que la obra, inconclusa, para nada puede mencionar la creación del hombre, lo que aquí perseguimos. Luego resulta, además, que el comentario fluye por un sentido literal y con frecuente censura a los abusos alegóricos ${ }^{74}$. Por último, hay serias dudas de que los escritos con cierto espiritualismo paradisíaco pertenezcan a san Basilio, y la crítica moderna atribuye sin titubeos el De virginitate, muy de nuestro caso, a otro autor, que es Basilio de Ancira ${ }^{75}$.

72. Cf. Expos. in Psalm. 50,7 (PG 27,240CD). M. AleXANdre, en: ATS 145, not. 119.

73. Cf. San Atanasio y el platonismo cf. en E.P. MEIJERING, Orthodoxy and platonism in Athanasius Synthesis or antithesis? Reprint winth corrections, Brill, Leiden 1974. Para la interpretación alegórica de los vestidos y la desnudez de los protoparentes, cf. Cont. Gentes, 3 (PG 25,8c-9A). R. Bernard 76ss.64ss. Además, cf. Paola Pisi, 111, not. 32.

74. Cf. J. Gribomont, In Tomos 29.30.31.31 Patrologiae Graecae. Ad editionem operum sancti Basilii Magni introductio auctore Joanne Gribomont. Ex officina Brepols 1961, espec. In t. 29, pp. 9ss; Basilio de Cesarea, Sur l'origine de l'homme (hom, $X$ et XI de l'Hexaéméron). Intr., text. crit., trad. et not. par Alexis Smes et Michel van Esbroeck, SCh 160 (Paris 1970) 20-24.81-98; Id., Homélies sut l'hexaéméron. Text. grec., intr. et trad. de Stanislas Giet, Sch 26 (Paris 1950) 47-69; J. Bernardi, La date de l'Hexaéméron de Saint basile, STPatr III (TU 78), Berlin 1961, 165-169.

75. Cf. F. CAvallera, Le «De virginitate» de Basile d'Ancyre, RHE 6 (1905) 5-14; J. CuEsta, Dieta y virginidad, MCom 14 (1950) 195, not. 26; P. Th. CAMELOT, Les traites "De virginitate», EtCarm (Paris 1952) 274.290: J. GribomONT, in t. 30, p. 4; Id., L'origenisme de saint Basile, en: AA.VV., «L'Homme devant Dieu». Mélanges offerts au Père Henri de Lubac, 1. Exégèse et Patristique, Paris 1963, 281-294: 286ss.291; asimismo, S. GIET, en: SCh 26, p. 51 y el índice; Paola Pisi, 109. 
Abunda el origenismo en las homilías y en la teología basilianas con no menor preferencia para lo teológico que para lo exegético. Sorprende algo percibir reflejos origenistas en las homilías de salmos y proverbios, siendo así que para el Hexamerón son de todo punto inadmisibles por las causas aducidas, aunque tampoco se debe silenciar que Basilio recoge en Philocalia textos del Genio alejandrino comentarista esta vez del Génesis ${ }^{76}$. Giet cree adivinarlos cuando san Basilio se percata, por ejemplo, de una aporía gramatical, o repudia los antropomorfismos o la materia increada, inclusive al afirmar con ciertas reservas una creación angélica anterior a la aparición del mundo visible. Gribomont camina por aquí más despacio ${ }^{77}$.

Dudosamente basilianas considera la crítica también las Orationes de la creación del hombre ${ }^{78}$. No pretendemos saber ahora si tales escritos pertenecen o no al gran obispo de Cesarea, sólo descubrir posibles vetas espiritualizantes al analizar crescite et multiplicamini. Lo primero que una y otra homilía parecen dejar claro es que su autor, el que sea, propugna la doble creación filoniano-origeniana ${ }^{79}$ y para él lo de a imagen de Dios no ha de aplicarse ni por lo más remoto al cuerpo, habida cuenta de que lo corpóreo es corruptible $y$, por ende, incapaz de ser imagen de lo incorruptible. De modo que mientras el animus fue hecho, la caro fue modelada ${ }^{80}$. Más importancia reviste la segunda por aquello de que su autor encara el multiplicamini con alegorismo análogo al de Orígenes, y en ella viene a decir que si por crescite hay que entrever la perfección y el crecimiento secundum Deum, o sea, lo propio del hombre interior (Katà Theón, teleiosin tèn katà tò éndon ánthropon) ${ }^{81}$, el multiplicamini procede adjudicarlo al katà tò Eúaggélion gennómenoi ${ }^{82}$. El aumento de las buenas obras proviene, siempre según su exégesis alegórica, del replete terram $\mathrm{y}$, desde planos escatológicos ocupado del retorno al primi-

76. Cf. K. Holl, Amphilochius von Ikonium in seiem Verhältnis zu dengrossen Kappadoziern, Tübingen 1904, 116-158; J. GRIBOMONT, L'origenisme de saint Basile, 286-288.

77. Cf. GiET, SCh 26, p. 17. Asimismo, SCh 160, p. 118; J. Gribomont, L'origenisme, 287.

78. Nos referimos a De Hom. structura Orationes I et II. Acerca de la autenticidad basiliana, cf. GIET, Saint Basile a-t-il donné une suite aux homélies de l'Hexaméront?, RSR 33 (1946) 317-358; D. AMAN DE MENDIETA, Les états de texte des homélies pseudobäsiliennes sur la création de l'homme, RBen 59 (1949) 4-54; J. GRIBOMONT, in t. 30, p. 2. Cf. también SCh 160, pp. 13-26; H.U. von Balthasar, Présence et pensée. Essai sur la philosophie religieuse de Grégoire de Nysse, Paris 1942, 152.

79. Cf. SCh 160 , p. 124 a propósito de poíesis (acción espiritual) de la $\mathrm{I}^{\mathrm{a}}$ hom., y de plásis (acción material) de la $\mathrm{II}^{\mathrm{a}}$.

80. Cf. De Homin. struct. Orat. II, I (PG 30,41A). De igual modo, II, 1 (col. 40D) De Homin. struct. Orat. I, 16 (PG 30,25A); I, 17 (col. 25B). Sobre originalidad y sitio de estas homilias, cf. SCH 160, pp. 116-126.231. not. 5 .

81. Cf. De Homin. struct. Orat. II, 2 (col. 44AB); II, 2(col. 41D) donde a cuento del Crescite et multiplicamini se pronuncia sobre un doble crecimiento: el del cuerpo y el del alma.

82. Ibid. II, 2. 
tivo estado edénico, califica la vida allí vivida de angelis sociam, como tòn ággélois ómo díaiton ${ }^{83}$.

Lo menos que se puede decir de Basilio de Ancira es que las aficiones espiritualizantes al comentar este pasaje genesíaco son tan claras cuanto indudables ${ }^{84}$. Es una glosa laudatoria de la virginidad la que le consiente exponer alegóricamente las nupcias y hacer ver la inexistencia de sexualidad en el primitivo plan divino. Del edén escribe sin tapujos que su bienhadada condición era incompatible con el comercio de la carne, implantado tras la prevaricación. Una vez mortal, a la naturaleza se le incorpora la función procreadora de los cónyuges. Después de la caída y de la expulsión del paraíso - diceAdán conoció sexualmente a la mujer, consolándose, mediante la sucesión de los hijos, del futuro mortal infligido a nuestra naturaleza ${ }^{85}$. Sumado a otros efectos pecaminosos, también el parto le induce a sostener, por lo menos de forma indirecta, que no debió existir matrimonio dentro del edén ${ }^{86}$. En resumen, que el matrimonio es una forma de inmortalidad (athanasia) por Dios establecida para remediar las secuelas del pecado. Con otras palabras, que las nupcias se contraponen en cuanto phthorá (corruptibilidad) a la aphtharsia (incorruptibilidad) de la virginidad, porque mediante ésta trascendemos el régimen mortal de vida humana hasta participar a nivel de existencia angélica en la eternidad, donde no existe ni antes ni después.

\section{SAN GREgorio. NACIANCENO (ca. 330-390)}

Comparte con el de Nisa la tesis de la virginidad primordial. Lo mismo las nupcias que la procreación, natural consecuencia suya, son efectos de la materia, de la carne, intrínsecamente disoluble. Por el contrario, la virginidad es superior al matrimonio, de la misma manera que la vida estable de los bienaventurados respecto de la transitoria de los mortales. Matrimonio y nacimiento corresponden al mundo de la materia y del incesante devenir, contrapuesto platónicamente a un superior nivel de estabilidad. Es la materia que siempre pasa, que perece - puntualiza-, la que inventó la unión sexual, que Dios luego regularía instituyendo el matrimonio ${ }^{87}$. Sólo la virginidad puede restituir, o si se prefiere restaurar ese momento en que la muerte no existía, estado éste del cual disfrutaba el hombre antes de la situación genesis-phthorá. A juicio de Gregorio Nacianceno la virginidad permite al hombre recuperar la

83. Ibid. II, 4.

84. Cf. De virginit. 3 (PG 30, 676A).

85. Cf. De virginit. 54 (col. 777B). Paola PISI, 109, not. 22.

86. Cf. De virginit. 54 (col, 777C).

87. Cf. Carm. I, 2, III, vv. 11-12 (PG 37, 633). Paola PISI, 103ss. 
integridad de los orígenes y trascender el tiempo que separa el archè del telos. El régimen de las nupcias lo provocó la caída original, y la virginidad es, ni más ni menos, y así de sencillo, la recuperación de aquella primitiva y bienhadada condición paradisíaca ${ }^{88}$.

\section{SAN GREGORIO DE NISA (ca. 335-ca.385)}

Con cierto filonismo en su antropología -De hominis opificio y De virginitate, un botón de muestra, guardan semejanza con De opificio mundi y De vita contemplativa - también Gregorio está por la doble creación, aunque discrepe en cuestiones de detalle ${ }^{89}$. Distinguir la corporeidad en sí de lo que se podría entender como espesor denso y pesante de la corporeidad humana actual, la de las túnicas de piel tras el pecado, es la notable diferencia que lo separa de Filón y más aún de Orígenes. Mientras para el último - sin olvidar tampoco algún que otro texto filoniano- la corporeidad viene añadida a las almas después de la caída, Gregorio opina que la segunda creación es contextual a la primera. Hay en Orígenes, además, una serie cronológica (preexistencia de las almas y de su caída en los cuerpos), en tanto que para Filón falta por dilucidar si entre el hombre a imagen y el plasmado media sucesión cronológica o sólo contextualidad. El filoniano hombre a imagen es, resumido, la idea platónica del hombre, el predecesor ontológico del hombre terreno. A Gregorio, por el contrario, se le alcanza que éste ni es idea platónica (Filón), ni la suma de almas preexistentes (Orígenes), sino la humanidad en su totalidad numérica por Dios creada y conocida. No es, pues, la doble creación un montaje o artificio para motivar el carácter místico del hombre y el primado de la imagen sobre la animalidad, que éste sería un poco el caso filoniano cuando el Judeoalejandrino distingue al hombre idea del hombre concreto. Gregorio trata más bien de relacionar la dimensión histórica con el mal uso que el hombre hace de su libertad. Tampoco Filón y Gregorio coinciden enjuiciando la caída, pues si el Judeoalejandrino aboga por la del hombre plasmado -el a imagen es idea y, por tanto, no susceptible de caer-Gregorio se inclina por la de la humanidad concreta ${ }^{90}$.

88. Cf. Paola PISI, 104s.

89. Cf. A. Slomkowski, 106, not. 3; J. Daniélou, Akolouthia chez Grégoire de Nysse, RevSR 27 (1953) 219-240; Id., Philon et Grégoire de Nysse, en: Philon d'Alexandrie, Paris 1967, 333-345; Id., L'être et la temps chez Grégoire de Nysse, Brill, Leiden 1970, 85-90; M. AUBINEAU, en: Grégoire de Nysse, Traité de la virginité, SCh 119 (Paris 1966) 116-118; M. AlexANDre, La théorie de l'exégèse dans le de Hominis opificio et l'in Hexaémeron, en: 'Actes 95-97; Id., Protologie et eschatologie chez Grégoire de Nysse, en: ATs 122-160.

90. Cf. U. BIANCHI, Presupposti platonici e dualistici nell'antropogonia di Gregorio di Nis- 
Hay quien niega que el Niseno defendiera la doble creación. Sólo habría dicho que existen, sí, dos expresiones escriturísticas al objeto de significar que el acto creador de Dios ha sido llevado a cabo desde dos aspectos: creación vista $a$ parte Dei, instantánea puesto que Dios está fuera y por encima del tiempo, y creación vista a parte hominum, desarrollándose a lo largo de la historia. Pero una sola creación, no dos. Lo que pasa es que Dios, valga insistir, creó al hombre histórico a imagen suya (eikón toù Theoú) o sea, perfecto, si bien con los mencionados aspectos: intelectual, a imagen de Dios (a parte Dei, kat'eikona), y sexuado, varón-hembra (a parte hominum), ya no imagen divina porque el arquetipo asomático — Dios - tampoco tiene sexo y análoga suerte deberá correr, en consecuencia, su kat'eikona. Ocurre asimismo que tal perfección habría implicado la multiplicación asexual. Asexual por lo dicho. Y multiplicación por contar con la angélica, o sea, con una fecundidad semejante a la de la Virgen. Sexuado y todo, el cuerpo no habría sido antes del pecado como el nuestro ahora, por desnudo aún de las túnicas de piel (dermátinoi xitónes). Huelga según esto el recurso a explicaciones platónicas o a una creación (kathólon) tipo estoico. Comentando el Génesis, pues, Gregorio expresa la intemporalidad del acto creador, pero abre, al hacerlo, dos cauces explicativos ${ }^{91}$.

A esto se oponen quienes propugnan la doble creación en Gregorio, los más. A las concordancias filonianas detectables en el Santo, muy estudiadas por Daniélou, añaden el platonismo y el estoicismo. Gregorio aborda la doble creación en De hominis opificio, 16. Doble creación.que cuenta con dos momentos distintos: el primero, del hombre a imagen de Dios (Gen 1,26). Su objeto de creación es la totalidad (tó pléroma) de la naturaleza humana, propio todo ello de la unidad ontológica presente en la presciencia divina. Diversa es la del segundo momento (Gen 2,7): previendo Dios con acto extratemporal la culpa humana, incorpora a su imagen el hombre modelado, el de la distinción sexual, el que exige participar ya de la vida irracional y animal ${ }^{92}$. Con antelación al pecado, pues, y previéndolo, crea Dios al hombre, varón y hembra, libre de instintos ${ }^{93}$. Curiosa también la nomenclatura. Gregorio designa al

sa, en: DCU 83-98; Id., «Addendum I»: Origene, Gregorio di Nissa e il platonismo, en: DCU 99. 102. Acerca de la exégesis, además de la not. 89, cf. B. DE MARGERIE, 240-269.

91. Por este sentido se inclinan E. Corsini, Nouvelles Perspectives sur le Problème des sources de l'Hexaëmeron, en: Actes 95-97. Y parece que H.U. von BALTHASAR, Présence et pensée, 52 , not. 5 .

92. Cf. J. Daniélou, L'être el le temps, 75-94; FL Floeri, 106-109; A. HMman, 118; M. AubineAu, SCh 119, pp. 98-101.103-116; U. BIANCHI, «Addendum II»: Ci sono ragioni per escludere in Gregorio di Nissa la teoria della 'doppia creazione' dell'uomo?, en: DCU 103-115; Paola PISI, 57-100: 57ss.

93. En un texto de suma importancia Gregorio hace ver que Dios, previendo la futura caí- 
hombre prelapsario con la división varón-hembra ${ }^{94}$, y al postlapsario, en cambio, con el término matrimonio (gámos), pequeño detalle si se quiere, pero que autoriza suponer que en el modo de pensar gregoriano la división sexual no exigiría necesariamente el matrimonio.

Entiende U. Bianchi, estudioso del tema, que la interpretación patrocinadora de una sola creación adolece de antropología "reductiva» y se echa en falta en ella una adecuada valoración de las motivaciones de la segunda intervención divina (no necesariamente temporal, repitámoslo, sino ontológica), pues separa la instauración de esta condición humana de desgracia de la temática relativa a la creación. No hay duda de que existe clara diferencia entre creación e imagen y creación aditicia, y que en ella la relevancia del pecado, no por ya cometido, pero sí en cuanto previsto por Dios, es grande. Gregorio por lo demás ni juzga tal pecado específicamente sexual ni lo identifica con la sexualidad. Pero los capadocios, él también, claro, sí lo reputarán condicionante del sexo ${ }^{95}$.

Otro gran argumento gregoriano es la virginidad de Adán. Del mismo modo que la sexualidad y su circunstancia desaparecerán tras la resurrección final ${ }^{96}$, así cabe imaginarla inexistente para el hombre prelapsario, enfoque éste común a Gregorio y Orígenes. El de la virginidad de Adán, o del telosarchè alcanza en Gregorio grandes resonancias y produce amplios efectos. No flojo problema constituye el averiguar cuánto pudieron influir en Gregorio a propósito de estos temas la tradición encratita moderada y las motivaciones platónicas. En cambio sale fuera de cuestión que la fisiología humana: nacer, crecer, engendrar, alimentarse, envejecer, morir quedará excluida del hombre resucitado, así como que el tema en cuanto tal es común a judaísmo y cristianismo, empezando por los conocidos logia de Mt 22,30, Lc 20,34-36 y Mc 12,25 . Como está claro, por último, que extender semejante exclusión al hombre prelapsario es muy origeniano, y platónico, y, hasta cierto límite, encratita, ya del encratismo absoluto, que no parece haber afectado en esto a Oríge-

da, modeló a su propia imagen algo irracional: división sexual (é katà tò árren kaì thélu diaforá). Cf. De hom. op. 22 (PG 44, 205AB); 16 (col. 185D); 17 (col. 189CD).

94. Plásma (Gen 2,7) indica la diferencia del sexo. Gregorio usa dicho término siempre que habla de Adán: cf. De hom. op. 16 (col. 185D); 22 (col. 204D.205A). Para la diferencia entre èpoíese y éplase, cf. In Verba «faciamus hom. Orat. II (PG 44, 280D); De beat. Orat. I (PG 44, 1197B). Asimismo cf. De hom. po. 15.16.17.22; M. NALDINI, Per una essegesi del «De hominis opificio» di Gregorio Nisseno (Cap. $V$ e XVI). Estratto dagli «Studi Italiani di Filologia Classica», Vol. XLV-Fasc. 1, Firenze 1973, 88-123.

95. Cf. U. BIANCHI, «Addendum II», en: DCU 109.

96. Cf. P. LANGa, S. Agustín y la condición sexual escatológica de la mujer, RelCult 25 (1979) 10-39; Paola PISI, 95ss. 
nes y los capadocios, ya del moderado, uno de cuyos afanes será, por cierto, igualar al Adán prelapsario con el resucitado ${ }^{97}$.

La doctrina gregoriana en torno a lo adicional de la sexualidad y la conexión genesis-phthorá constituye la base ontológica de su tesis sobre la virginidad, que recupera el archè y anticipa el telos. El retorno a la belleza y beatitud paradisíacas del Adán prelapsario ha de hacerse recorriendo a la inversa el camino de los progenitores al salir expulsados del edén, posible gracias a que la virginidad es propia de Dios, o sea, es aphtharsia (incorruptibilidad), vencedora de la muerte y corrupción ocasionadas y traídas al mundo por el pecado adánico. La virginidad como aphtharsia, superior al régimen genesis-phthorá por restauradora de la primordial situación de los progenitores y anticipadora de la de isaggelia final, la tesis en suma de la virginidad de Adán y de la institución postlapsaria de las nupcias no es invento de Gregorio, dependiente en ello de la patrística griega, de la especulación encratita hasta cierto punto heterodoxa y, sobre todo, del platonismo, verdadero inspirador en los Santos Padres $\mathrm{y}$ en el encratismo heterodoxo ${ }^{98}$.

Gregorio analiza crescite et multiplicamini en De hominis opificio, 17. Contempla la hipotética modalidad multiplicadora de una humanidad prelapsaria, y la del actual orden creado. Sin aquella transgresión los hombres habrían sido lo que el día que resuciten: como ángeles que ni se casan ni toman mujer (Lc 20,35) ${ }^{99}$, pero que se reproducen angélicamente. Pues bien, concluye Gregorio, de análoga forma cabe suponer la multiplicación humana en caso de no haber prevaricado Adán ${ }^{100}$. Previendo el tropiezo, Dios crea al hombre sexuado, y después de lo cual le ordena: crescite et multiplicamini (Gen $1,28)$, a primera vista matiz de suma importancia, ya que deja suponer que, para el Santo, Dios habría dispuesto la multiplicación animal desde el principio ${ }^{101}$, pudiéndose reproducir, perfecto y todo como era, y de propo-

97. Cf. U. Bianchi, DCU 109-110; M. Alexandre, ATs 135.143-144.

98. Cf. De hom. op. 17 (col. 188C); In Eccl. hom. I (PG 44,633C); In Cant. hom. 7 (PG 44,916B). Hay pasos también en De an. et res. Cf. Paola PiSI, 95-100.

99. Cf. De hom. op. $17 / \mathrm{col} .188 \mathrm{C})$.

100. Cf. De hom. op. 17 (col, 188D.189ABC). A lo largo del c. 16 del De hom. op. Gregorio se ocupa del hombre imagen de Dios, paso inmediatamente anterior al que aquí referimos, imprescindible para comprender el entorno general. Para ello, cf. J. LAPLACE, Intr., en: Grégoire de Nysse, La création de l'homme, SCh 6 (Paris 1943); H.U. von BALTHASAR, Présence et pensée, 41-81; A. Slomkowski, 109-118 E. Corsini, en: Actes 113-126; J. Daniélou, L'être et le temps, 90-94. Sobre la reproducción angélica en el hombre prelapsario, cf. F. FLOERI, La «division des sexes» chez Grégoire de Nysse, RevSR 18 (1953) 105-111: 109ss.; Dom M.G. ColombÁs, Paradis et Vie angélique, Paris 1961, 30ss;. A. ORBE,, 253. not. 92; Paola PISI, 57-100.

101. Cf. De hom. op. 22 (col. 205AB); De virginit. 12 (PG 46,376A); 13 (col. 377B). Asimismo, cf. SCh 119, pp. 433-437. 
nérselo, no a la manera angélica sino sexual, como los animales. La suposición no obstante se desvanece porque la realidad no fue así, ya que -el mismo Gregorio lo puntualiza - sólo después de cometido el pecado empezó la generación sexual. En resumen, a Gregorio le va de modo inexcusable la sentencia de un hipotético multiplicamini asexual. En qué hubiera consistido es detalle al que no desciende, si bien sugiere algo cuando la define como «indecible e inimaginable para las conjeturas humanas», lo que está lejos de significar irrealidad ya que - afirma - es seguro que hubiera podido darse ${ }^{103}$.

\section{SAN JUAN CRISÓSTOMO (344/54-405)}

A simple vista parece fuera de lugar que figure aquí un autor que por geografía, formación y clima cultural pertenece a los antioquenos. Lo cierto es que, por más que su planteamiento sea a las veces distinto, defiende conclusiones similares por no decir idénticas a las de Gregoria de Nisa ${ }^{104}$. De oratoria brillante, sensible a las costumbres del tiempo, práctico como los antioquenos, afanado siempre por inculcar la ascesis, Juan Crisóstomo predica las homilías entre parangones y contrastes sobre temas como la oración, el monacato, la virginidad, la caída de Adán, etcétera ${ }^{105}$.

Más que crescite et multiplicamini concentra su atención en la raíz de la grandeza humana que representa el faciamus hominem (poiésomen ánthropon), extensivo por igual al hombre y la mujer ${ }^{106}$. El a imagen divina con que los autores precedentes especulaban alegóricamente sobre espiritualismo, doble creación, asexualidad, no suscita en él disquisiciones tan, diríase, bíblicometafísicas. Le preocupa la pastoral, lo que tenga garra para llegar al pueblo.

102. Cf. De virginit. 12 (col. 374D. 376A); De hom. op. (col. 188AB); De an. et res. (PG 46, 128C). La interpretación alegórica de las túnicas de piel, cf. en: De Orat. Dom. V (PG 44, 1184BC).

103. Cf. De hom. op. 17 (col. 189A).

104. Téngase en cuenta que la vida de san Juan Crisóstomo la enmarcaron dos famosas ciudades: Antioquía y Constantinopla. Ver un estudio para cada una en Chr. BAur, Der Heilige Johannes Chrisostomus und seine Zeit, München 1929 (vol. 1: Antioquía) y 1930 (vol. 2: Constantinopla). Cf. además L. MEYER, Saint Jean Chrysostome maître de perfection chrétienne, Paris 1934, 1-43; Th. SPIDLík, Il matrimonio nel pensiero del Crisostomo, Aug. 17 (1977) 221-226: 224; Paola PISI, 105-109.

105. Su propensión a la ascesis y el puesto, dentro de ella, de la virginidad resultan casi paradigmáticos. Muy comprensible todo ello advirtiendo que salió del monaquismo para la sede patriarcal de Constantinopla. Ver al respecto A. PUECH, St. Jean Crysostome et les moeurs de son temps, Paris 1891, 318-324; L. Meyer, 185-214; B. Grillet, Intr. en: S.J. Chrysostome, La virginité, SCh 125 (Paris 1966) 8-37.

106. Cf. In c. II Gen. hom. 14,3 (PG 53, 113s); In c. I. Gen hom. 10, 3 (PG 53, 85); In Gen. serm. IV, 1 (PG 54, 594); L. Meyer, 196; A. HAMmAN, 109s. 
De ahí que insista más en cómo Dios adornó al primer hombre de inmortalidad, de cuerpo incorruptible, como ángel terrestre (aggelon epígeion), en catástasis angélicas que forzosamente demanda amistad divina y ésta, a su vez, envidia del demonio. Un Adán, en suma, libre de turbios instintos 107.

Pero en cuanto comentarista de lo paradisíaco se revela en buena parte niseno: la virginidad era allí lo primero ${ }^{108}$. De tanto elogiarla parece que desenfoca a veces el matrimonio. En De virginitate coloca el origen del matrimonio en la caída, y relaciona lo que atañe a la generación (genesis) con la currupción (phthorá). Jamás disocia el matrimonio de la muerte: el uno es remedio y consuelo frente a la otra, introducida en el mundo por el pecado. La institución matrimonial postlapsaria retorna a las homilías del Génesis. Juan Crisóstomo pone de relieve en ellas que antes de la desobediencia, nuestros primeros padres vivían como los ángeles, sin relación sexual alguna. Como se ve, al fondo asoma siempre la virginidad. Y ésta es la razón de que cuando se ocupe de las molestias matrimoniales (molestiae nuptiarum) lo haga con el fin, antes que nada, de que por contrapunto sobresalgan más y más las ventajas virginales. No dirá del matrimonio que es pecado, pero sí que no entraba en el plan creador, de modo que sobrevino después de la primera caída, como sucedió con la concupiscencia, la muerte y la corrupción. El matrimonio según estas razones es efecto de la desobediencia paradisíaca, dado que Dios lo instituyó sucedáneamente, para que el género humano se reprodujera neutralizando así los estragos de la muerte ${ }^{109}$. Entiéndase bien que, pese a escribir de las nupcias con nostalgia de la virginidad perdida, Juan Crisóstomo sabe dar con el aspecto medicinal y bueno de la institución, y la califica de remedio y control y cauce de la concupiscencia. Frente a la muerte hace ver que las nupcias son, además, imagen de la resurrección (eikón anastáseos). Y una gracia, una

107. Cf. In c. II Gen. hom. 16, 1 (col. 126); In c. II Gen. hom. 15,4 (col. 124); Ad Pop. Antioch. hom. 11, 2 (PG 49, 121); In Ep. ad Cor. hom. 9, 1 (PG 61, 76). A. SlomkowSK1, 79s.

108. A juicio de san Juan Crisóstomo el ideal de perfección consistía en hacerse uno en la tierra como un ángel del cielo. La cúspide aquí, la virginidad. Ser ángeles y semejantes a Dios era, a su entener, la síntesis del mundo sobrenatural, resultado de la restauración de Cristo. En el paraíso el hombre había gozado de una deliciosa situación virginal con la que acabó el pecado. En orden a toda esta problemática, cf. A. Moulard. St. Jean Chrysostome, le défenseur du mariage et l'apôtre de la virginitá, Paris 1923, 60-70; F. DE B. VIZMANOS, Las Virgenes cristianas de la Iglesia primitiva, Madrid 1949, 34-43; P. LANGA, Equilibrio agustiniano entre matrimonio y virginidad, RA 21 (1980) 73-134: 102; ver, además, A. PUECH, 93-100; M.G. Colombás, 28-33; L. MEYER, 192-202; A. SLOMKOWSK1, 79-90.119-131; SCh 125, 8-37.57-70.

109. Cf. In c. IV Gen. hom. 18, 4 (col. 153); In c. IV Gen. hom. 20, 1 (col. 167); In Gen. serm. IV, 1 (PG 54, 594); De mundi creat. Orat. VI, 4 (PG 56, 489); De virginit. 14 (PG 48,544); 15 (col. 544); In illud: Propter fornic. I, 3 (PG 51, 213). SCH 125, 56s.60s; A. Moulard, 64-67. Ver además a C. SCAGLIONI. Ideale coniugale e familiare in san Giavanni Crisostomo, SPM 273422: 274ss. 285 . 
concesión divina, un don salvador al permitir a los más débiles sobrellevar el yugo de la castidad ${ }^{110}$.

Pero vengamos a las modalidades del hipotético multiplicamini. La inexistencia de relaciones sexuales en el paraíso, antes de la caída, obedece según el entender de Juan Crisóstomo a que el instinto no abrasaba las carnes de Adán y Eva, incólumes aún "'. Allí reinaba la virginidad. Y tanto la elogia que incurre en contradicciones. Así, las palabras de Adán a la virago, en las que la Iglesia tradicionalmente ha visto la institución matrimonial, Juan Crisóstomo las interpreta en clave profética de algo que ha de suceder. Igual acontece con Gen 1,28. Lo que pasa es que no puede eludir la problematicidad que provocan preguntas así: ¿Cómo compaginar la reproducción con la virginidad si por ccncepto son excluyentes? ¿Cómo entender el multiplicamini sin procedimiento sexual? ${ }^{112}$.

El Crisóstomo se las ingenia para salir airoso del atolladero: si la pareja era inmortal, precisará, la reproducción (para remediar la mortalidad) sobraba. Más aún, de quererlo Dios hubiera arbitrado modos asexuales para multiplicar el género humano. O sea, radical rechazo del sexo y de la reproducción sexual. Ser angélicos era ser vírgenes, libres del comercio carnal ${ }^{113}$. La virginidad, sí, hace inviable toda relación del sexo, pero tampoco hubiera impedido a Dios reproducir el género humano a la manera usada, por ejemplo, con Abrahán (devolviéndole la joven lozanía), dando así descendencia no por el matrimonio, sino en virtud de la misma fuerza generadora del divino crescite et multiplicamini ${ }^{114}$. De donde sale que Dios, siendo así, podría haber multiplicado la humanidad por creaciones sucesivas de hombres adultos, como Adán. Al fin, ni Adán ni Eva nacieron como nosotros ni miríadas angélicas empezaron a existir como los hombres después del primer pecado. Luego Dios pudo perfectamente arbitrar otros sistemas asexuales ${ }^{115}$. Sería injusto, esto

110. Cf. Quales ducendas sint uxores, III, 5 (PG 51, 232); In illud: Propter fornic. I, 3 (col. 213). Paola PISI, 108-109.

111. Cf. In c. II Gen. hom. 15, 4 (col. 123s); In c. IV Gen. hom. 18, 4 (col. 153).

112. Las palabras que el Crisóstomo interpreta en clave profética, como de algo por suceder son; «os ex ossibus meis, et caro de carne mea: haec vocabitur virago, quoniam de viro sumpta est» (Gen 2,23-24). La tesis en cuestión aparece: desarrollada en los cc. 14-15 del De virginitate. Ver también In c. II Gen. hom. 15, 4 (col. 123) Con gran sorpresa para cualquier tratadista, el Crisóstomo coloca el divino Crescite et multiplicamini $(\operatorname{Gen} 1,28)$ inclusive después de cometido el pécado. Ver In psalm. 113, 5 (PG 55, 312).

113. Ver la nota 108. Indudablemente san Juan Crisóstomo, por más que sus preferencias vayan por el sentido literal y sea él mismo de raigambre antioquena, recurre algunas veces al sentido espiritual de la Escritura, como en este caso que nos ocupa. Cf. A. Moulard, 64ss.

114. CF. De virginit. 15 (PG 43, 544).

115. Cf. In illud: Propter fornic. 1, 3 (col. 213); De virginit. 14 (col. 544). 
también, omitir que al reanudar más tarde el mismo texto escribe menos rotundo. Con todo, nunca retrocederá de lo avanzado aquí ${ }^{116}$. Las conclusiones entonces salen análogas a las de Gregorio de Nisa, con independencia de que cada uno reúna matices peculiares y puntos de vista diferentes a lo largo del análisis.

Digamos para cerrar este capítulo de escritores griegos que, si no con la claridad del Niseno y del Crisóstomo, es presumible similar interpretación en algún que otro pasaje de la patrística griega del siglo IV, con probabilidad donde se aboga por la institución postlapsaria de la generación carnal, o donde la multiplicación por vía de sexo es signo de animalidad. Según la crítica, a ello parece que alude la conocida como Homilía anatólica sobre la Pascua ${ }^{117}$.

\section{SAN Ambrosio (337/39-397)}

Aunque latino, procede coherente con la mentalidad analizada de los griegos, de particular manera por lo que atañe a su exégesis en el Hexamerón, De paradiso, y De Noe. Hay en el Hexamerón innegables huellas de Orígenes, Basilio, Filón, Suetonio, Apuleyo, Plinio y Galeno ${ }^{118}$. El sentido literal no impide al alegórico y a las explicaciones morales imponerse a menudo ${ }^{119}$. De paradiso delata indicios filonianos no menos evidentes. Lo que en De opificio mundi, 59 el Judeoalejandrino interpreta alegóricamente de Adán (mente, razón, noús), y de Eva (sentido, aísthesis), y del diablo (delectatio, voluptas) pasa casi calcado a los números 11-12 del De paradiso ${ }^{120}$. La creación del hombre y su posterior traslado al edén sugiere a todas luces la doble creación. También De Noe arroja claras influencias del filoniano Quaestiones et solutiones in Genesim ${ }^{121}$. En punto a temas virginales influye san Atanasio, y para

116. Cf. De virginit. 17 (col. 546).

117. Cf. Paola PISI, 110-111: not. 28.

118. Cf. San Jerónimo, Epist. 84, 7 (PL 22, 749); san Basilio, Epist. 197 (PG 32, 709-713; CSEL 32/1, al pie de pp. 5.39.46.126.222 etc). C. MoRINo, Ritorno al Paradiso di Adamo in S. Ambrogio. Itinerario sipirituale, Tip. Poligl. Vaticana 1952; W. SEIBEL, Fleisch und Geist beim heiligen Ambrosius. Münschener theologische Studien, II.Systematische Abteilung, 14 Band, München 1958; G. LAZZATı, Il valore letterario della esegesi ambrosiana, Milano 1960; G. MADEC, L'homme Intérieur, en: AA.VV., Ambroise de Milan, XVI Centenaire de son élection épiscopale, Paris 1974, 283-308.

119. Curiosa, por ejemplo, esa observación de que el buitre se reproduce sin cópula (Hexam. V, 64-65), un caso más para no ver imposible que la Virgen concibiera sin concurso de varón. Cf. también Hexam. VI, 4; VI, 6 (CSEL 32/1, pp. 206-208).

120. Ver similar explicación en De Abraham II, 1 (CSEL 32/1, pp. 564s), donde también asoman indicios filonianos.

121. Cf. De parad. nn. 24-25 (CSEL 32/1, p. 280). L.F. Pizzolato, La coppia umana in sant'Ambrogio, SPM 180-211: 181ss. 
exégesis los ya citados Filón, Orígenes y san Basilio. Cicerón, los platónicos y no pocos filósofos de la época arrimaron material, pero Ambrosio supo mantenerse él mismo en las homilías. Como san Juan Crisóstomo, brilló más como pastor que por lo metafísico y exegético ${ }^{122}$.

A través de sus escritos se percibe clara la diferencia entre el hombre hecho y el plasmado. No está rotundamente firme, pero sí desliza por sus páginas la doble creación, al menos cuando sigue la exégesis filoniana, doble creación que puede entreverse por frases como unam secundum imaginem Dei, alteram secundum figmentum de luto terrae ${ }^{123}$. Atrás quedan escritores que interpretaron el paraíso utilizando la clave alegórica ${ }^{124}$ y enjuiciando lo somático como añadidura postlapsaria. Discierne san Ambrosio entre el hombre esencial, incorpóreo, y el histórico y modelado de la tierra. Modelado fuera del paraíso e introducido luego allí, con lo que a juicio de nuestro autor hay paraíso histórico y hombre histórico, que es del que se ocupa. Debajo de tales pensamientos está entrevisto que subyacen los de la virginidad paradisíaca y, consecuentemente, la unión sexual postlapsaria ${ }^{125}$.

De crescite et multiplicamini apenas escribe. En la naturaleza prelapsaria entiende el obispo milanés a un Adán dotado de gracia, o si se quiere amistad divina, revestido de inmortalidad, inocente, con cuerpo espiritualizado ${ }^{126}$ al que le serán endosadas después de la caída las túnicas de piel ${ }^{127}$. Con ello cabe preguntarse: ¿afecta dicho cambio a la modalidad del multiplicamini? La hipotética reproducción antelapsaria ¿habría sido espiritual o material (animal) como es hoy? Si el cuerpo de Adán era espiritual, por pura lógica no se admitiría otra alternativa que la de la multiplicación también espiritual. Deducción

122. Cf. Y.-M. Duval, Originalité $d u$ «De virginis», en: Ambroise de Milan, XVI Centenaire, 9-66: 29-60.64-66; G. LAZZATI, 25-27.40.58.59-64.77-78.99, not. 105; P. COURCELLE, Recherhes sur saint Ambroise, Paris 1973, 17-23; G. MADEC, Siant Ambroise et la Philosophie, Paris 1974, 36-45.57-60.

123. CF. A. ORBE, El día de la creación del hombre según teólogos del s. II, EE 42 (1967) 297-330: 299, not 4; A. FIERro, Sobre la gloria en S. Hilario, Roma 1964, 9ss. Ver en san Ambrosio, De Noe 24, 86 (CSEL 32/1, pp. 474s).

124. Los mismos gnósticos llegaron a defender ambos cuerpos: sutil, invisible, el del día sexto; «carnal», de materia crasa, mortal, el del día octavo, a raíz de la caída. Cf. A. OrBe, El día de la creación, 322, not. 93.94.97; C. MORINO, 1ss.

125. Cf. Paola PISI, 111-114: 113.

126. Cf. A. Slomkowski, 136-141; C. Morino, 1-30: 4-7.73ss.

127. En los alegóricos estos vestidos suelen significar el castigo por el pecado. Para quienes distinguen la creación a imagen de Dios de la creación del hombre terrestre, el signo de lo corpóreo. En quienes distinguen dentro de un hombre histórico, dotado desde el principio de cuerpo, el signo de la «materialidad» que el cuerpo contrae tras el pecado. Sobre el contraste de tales doctrinas entre Ambrosio, 40-69. 
implícita la nuestra ${ }^{128}$, por supuesto, pero que consienten por lo menos no sólo el análisis contextual precedente sino diversos textos ambrosianos acerca de un Adán virgen cuya vida paradisíaca era angélica, y que perdió tan pronto como se produjo la infracción ${ }^{129}$. El obispo de Milán, por tanto, no integra la corriente anterior desde el análisis alegórico, pero sí por la virginidad de Adán. La vida del edén no era, en su opinión, angélica sólo por carecer de sexo, sino también porque allí, tal y como el Niseno escribe, el hombre no ejercía ninguna función fisiológica, libre como entonces estaba de corporeidad terrestre y corruptible ${ }^{130}$.

\section{SAN JERÓNIMO (347-420)}

Más que a la elegoría, de importancia en él, sus juicios espiritualizantes responden, como es el caso de Juan Crisóstomo, a un previo desenfoque del matrimonio provocado por el excesivo culto a la virginidad. De ella se resiente nostálgica su opinión del edén. Estamos, la cosa es clara, en pleno argumento de la virginidad de Adán ${ }^{131}$. El cuerpo sexuado, al servicio de la sucesión del género humano, al objeto de que brevitatem humanae vitae vincat successione perpetua ${ }^{132}$, en cierto modo fruto del pecado nos emplaza ante la típica tesis de las nupcias postlapsarias. A pesar de ello, san Jerónimo andará cauto y no caerá en la trampa de reputar el matrimonio malo en sí. Opina que la del Creador es imagen que non habet copula nuptiarum. Por eso, el replete terram debe ser entendido como que las nupcias terram replent, virginitas paradisum ${ }^{133}$. Las túnicas marcan el principio del matrimonio ${ }^{134}$. La virginidad adánica, por tanto, y la sexualidad postlapsaria son tesis a las que se suma el monje de Belén.

San Jerónimo, sin embargo, no parece atreverse a emitir ningún juicio concreto sobre la modalidad reproductora de una hipotética humanidad pre-

128. Como occidental, Ambrosio se muestra poco explícito. El mismo Jerónimo irá más allá en el campo virginal. Cf. A. SLOMKOWSK1, 141.

129. Cf. De inst. virg. 17, 104 (PL 16, 345): «innumerabiles gratias agimus, quod in virginibus sacris angelorum vitam videmus in terris, quam in paradiso quondam amiseramus». Además, Epist. 45, 6 (PL 16, 1192); 45, 13 (col. 1193).

130. Cf. Paola PISI, 112: not. 33.

131. Se acusa una vaga alusión a la pérdida de la inmortalidad y con ello de ese estado virginal, ya que el matrimonio parece aquí que fue instituido para remediar las bajas de la muerte, sobrevenida como castigo del pecado.

132. Cf. Epist. 100, 12 (PL 22, 823, CSEL 55/1, p. 225).

133. Cf. $A d v$. Iov. I, 16 (PL 23, 246BC).

134. Cf. Epist. 22, 19 (PL 22, 406, CSEL 54/1, p. 168): «Eva in paradiso virgo fuit; post pelliceas tunicas initium nuptiarum... virgo nascitur caro de nuptiis in fructu reddens, quod in radice perdiderat». Ver Epist. 79, 10 (PL 22, 732, CSEL 55/1, p. 99). 
lapsaria. Y cuidado que se lo propone, pero no acierta a pronunciarse. Fluctúa indeciso, eso parece, hasta que acaba inclinándose por la virginidad paradisíaca: sólo después de su expulsión del edén empezó para los protoparentes el matrimonio. ¿Y de no haber caído? Por toda respuesta Jerónimo se refugia detrás de un incertum est ${ }^{135}$. Intuye que por coherencia con la exposición anterior desembocaría sin remedio en la multiplicación espiritual, o asexual, pero se resiste, y, dubitativo, prefiere acogerse a los divinos arcanos y de nuevo concluir que la llamada a reinar en el paraíso era la virginidad: qui in paradiso virgines permanserunt, eiecti de paradiso copulati sunt. $\mathrm{Y}$ más adelante reitera: quod ibi (paraíso) non fecerunt, in terra faciunt, ut statum a principio conditionis humanae virginitatem paradisus, a terra nuptias dedicaverit ${ }^{136}$. Invalidando las evasivas por exclusión, se nota que no tiene escapatoria y que su recaladero final sería el de los últimos autores analizados.

\section{CONCLUSIONES}

Cubierto el itinerario preagustiniano, procede sacar algunas conclusiones que faciliten una rápida y sencilla comprensión de lo expuesto. Gen 1,28 reviste significados de carácter protológico y escatológico a inscribir dentro del más ancho margen de la antropología general y de la ontología, y con los subsiguientes matices de las interpretaciones exegéticas y de su repercusión teológica. No es tema exclusivamente patrístico, ni sólo bíblico, pues de él, y a su manera, trataron antes corrientes filosófico-religiosas antiguas las cuales, como en páginas atrás queda enunciado, habrían de indicir más o menos en la tarea exegético-teológica de los Santos Padres. Hay en el análisis patrístico, siendo así, causas ontológicas, protológicas y escatológicas heredadas - con raigambre más o menos profunda según los casos- de antropologías dualistas tipo platónico, sobre todo, sin excluir las de carácter encratita, seguro el moderado. Influyen asimismo para otros problemas afines, en este quizás no tanto, el gnosticismo y el estoicismo. Lo que de específico guardan las concepciones aquí dichas - filtradas hasta Orígenes vía Filón, y por él a los demás autores revisados- es que no sólo continúan el dualismo platónico sino que, al utilizarse en orden a explicar el dato revelado, lo agravan.

135. Cf. $A d v$. Iov. I, 29 (col. 263A).

136. Cf. $A d v$. Iov. I, 29 (col. 263A). Y el mismo Jerónimo se pregunta: «Aut quid nocebat, si paradisus nuptias recipit, et nulla est inter maritatam virginemque diversitas, etiam in paradiso eos ante sociari»? Cf. Paola PiSI, 114: not. 37. 
Para los autores que anteceden, Dios es, ciertamente, el creador universal, sólo que su proyecto creativo y la ejecución del mismo los modifica una caída. La más notoria característica del referido dualismo, al respecto por supuesto, será precisamente insistir en que tal pecado condiciona las intervenciones segundas de Dios. Este montaje lo levantan unos partiendo de las diferencias antropológicas a que Gen 1,26 y Gen 2,7 conducen, otros en cambio, propenden a la virginidad de Adán como aphtharsia y entonces arrancan no tanto de la doble creación de los textos anteriores cuanto de las desigualdades surgidas de Gen 2,7 (hombre modelado, histórico, virgen) y Gen 3 (el hombre al que se le endosan las túnicas de piel, que significan la mortalidad, la sexualidad y, a la postre, el mismo matrimonio).

Ninguno afirma que el matrimonio sea, en sí, un mal. Por las razones aducidas todos rebajan, sin embargo, su valor, no pocas veces con el fin de realzar a su costa y elogiar en demasía el de la virginidad. Dentro de los alejandrinos puros lleva a esta desestima un comprobable influjo platónico adverso a la materia, sin desdeñar consideraciones estoicas y encratitas. Ya se sabe que al objeto de que en sus vidas primara el espíritu de la apatheia los de la Stoa intentaban por todos los medios superar. los instintos.

Los elogios virginales responden a la imperiosa obligación de reprimir laxitudes y costumbres torpes, contrarias por fuerza a dicha virtud. Los alejandrinos actuarán, como siempre, desde planteamientos especulativos y con perspectiva exegético-teológica. A los simpatizantes de lo antioqueno, inclinados hacia interpretaciones más éticas y menos teológicas, más pastorales y menos especulativas que los anteriores, los moverán motivos ontológicos y protológicos de corte encratita. El encratismo presenta la virginidad como la única vía salvadora porque es la sola forma de vida que responde a la voluntad del Creador. Vivir la virginidad como aphatharsia significará, sí, vivir la vida de los resucitados, pero al mismo tiempo restaurar la integridad de los orígenes. Desde san Atanasio se empieza a detectar, interfiriéndose una y otra vez, esta línea. Las del platonismo y encratismo son, al fin y a la postre, raíces comunes, aunque su longitud pueda variar. Todo será cuestión de insistir, más que en la doble creación de los alejandrinos (Gen 1,26-Gen 2,7), sobre el hombre modelado de Gen 2,7 y el sexuado de las túnicas pelíceas de Gen 3, distinguiendo, dentro de este hombre histórico, el Adán antelapsario del postlapsario.

A todos incomoda el masculum et feminam fecit illos (Gen 1,27) y en unos y otros se descubre, ora explícita, ora implícitamente, la tesis de la doble creación para resolver el problema. Desde Filón-Orígenes, sobre los alegóricos pesará el convencimiento de que lo corpóreo es añadidura post peccatum, 
pues la imagen divina no se aviene con lo sexual, ni con la corporeidad pesante y perecedera. El paso siguiente será afrontar el multiplicamini con análisis alegórico. Se ha visto que Orígenes interpretaba tal vocablo en el sentido de los buenos y malos pensamientos (varón-hembra). La hipotética reproducción prelapsaria la enfocaba él desde las elevadas alturas de lo espiritualizante y místico. A ello conviene sumar que en los de ámbito antioqueno es fácil vislumbrar también la proclividad a excluir del primitivo plan creador de Dios la división sexual, que sobreviene después del pecado. Marginan por así decir el esquema alejandrino de la doble creación -hombre ideal (Gen 1,26$)$ y hombre modelado (Gen 2,7) - y atienden el histórico con un antes y un después, dotado de cuerpo terrestre aunque angélico al principio, hasta que, una vez cometida la falta, se le añade el sexo. Inclusive Gregorio de Nisa, que admite la división sexual antes de la caída, hace ver que aparece previendo Dios ese futuro pecado. Igual suerte interpretativa que el sexo, como es lógico, corre el matrimonio, remedio y consuelo de cara a la muerte, medicina contra la concupiscencia y, resumiendo, algo inconcebible de no haber tenido lugar tal prevaricación.

La dificultad entonces surge inevitable: ¿y en la hipótesis de un multiplicamini prelapsario, qué? Porque la humanidad se tendría que haber reproducido dado que el multiplicamini regía antes del pecado (con la sensible excepción de Juan Crisóstomo, dato curioso). La mayoritaria respuesta es que el multiplicaos no lo lleva a cabo la pareja hasta después de la caída. Atrás queda la sentencia origenista de la multiplicación espiritualizante o mística. Quienes se inclinan por la virginidad de Adán en el paraíso recurren a la reproducción asexual. Gregorio de Nisa y Juan Crisóstomo aportan soluciones peregrinas al problema: por creaciones sucesivas a la manera de Adán adulto, como se reproducen los ángeles, gracias a especiales intervenciones divinas, como la del caso de Abrahán, un suponer. Todo menos acudir al procedimiento carnal del sexo. Es decir, que tanto unos como otros adolecen de indisimulable fobia antisexual, heredada del encratismo y, a fin de cuentas, del platonismo, por más que reste aún por esclarecer en qué proporción y bajo qué formas.

El panorama doctrinal de estos autores se corresponde, pues, con el cuadro que san Agustín esboza en De bono coniugali 2,2. He aquí una corriente patrística influenciada de platonismo, encratismo, el moderado al menos, estoicismo y puede que gnosticismo, pues cuenta con ramificaciones en lo que atañe a matices. He aquí, en todo caso, a los autores con seguridad aludidos por el Obispo de Hipona en su plures enim de hac re sententiae diversaeque extiterunt. He aquí, por fin, las raíces que lastraron la hermenéutica patrística y que, teológicamente hablando, habían de repercutir negativas en la valoración del matrimonio. Con unos condicionamientos así, se comprende mejor el 
clima enrarecido, por no decir de hostilidad, que las nupcias vivieron durante las primeras centurias del cristianismo. Poca teología, y pobre, cabía esperar de semejantes posturas. San Agustín encontró este estado de cosas. Veremos en la segunda parte qué hizo.

(continuará)

P. LANGA 